\title{
Omani Arabic: More than a Dialect*
}

\author{
Rashid Al-Balushi ** \\ (Sultan Qaboos University, Oman)
}

\begin{abstract}
This paper surveys several linguistic aspects of the varieties of the Omani Arabic dialect (OA). It starts with a discussion of the sociolinguistic situation in Oman and the factors that shaped it, as well as discussing the OA varieties and the languages spoken in the country. This is followed by a presentation of the OA consonant and vowel phonemes and their allophones. The paper also presents phonological aspects such as syllable structure and word stress as well as examples of processes like assimilation and emphasis spreading. Then, it presents the OA personal, demonstrative, possessive, and interrogative pronouns, as well as morphological issues such as subject agreement affixes, verbal forms, passive formation, and pluralization patterns. Next, it presents syntactic patterns including word order, negation, question formation, and relative clauses. Besides the survey, the paper provides examples that reveal similarity between some OA dialects and those of the pre-Islamic era, as evidenced by some of the documented and approved readings of the Holy Qur?ān. There is also discussion of some cases of grammaticalization and pronominal copulas.
\end{abstract}

Keywords: Omani Arabic dialects, phonemes and phonological processes, pronouns, verb structure, negation particles.

\section{Introduction}

This paper aims to demonstrate the richness and complexity of OA by presenting many of the properties and patterns of its various dialects and the differences between those dialects. Where possible, the paper also highlights the similarities and differences between $\mathrm{OA}$ and other varieties of Arabic, including Standard Arabic (SA), with respect to the

\footnotetext{
${ }^{*}$ I would like to thank Clive Holes for providing some of the readings necessary for this survey. Thanks are also due to Khalsa Al-Aghbari for comments on an earlier version of the paper, as well as to my students for help with the data.

** Rashid Al-Balushi: Assistant Professor of Linguistics, Department of English Language and Literature, College of Arts and Social Sciences, Sultan Qaboos University, Oman. E-mail: rash5222@yahoo.com, rash5222@squ.edu.om.
} 
examined structures and properties, with the goal of making OA available for comparative linguistic analysis. The OA dialects have almost the same syntax. The differences in terms of phonetics, phonology, and morphology are more noticeable. The discussion of the various linguistic issues will make reference to $\mathrm{OA}$ as one dialect, but it will mention which variety is relevant to the issue under discussion, and where the various varieties differ. Given its scope, the paper will not provide theoretical accounts of the data. Instead, it will highlight the potential areas for future investigation.

The Bătina sedentary dialect is the author's own, and the Dhofări sedentary dialect is the author's spouse's. The following abbreviations are used:

Acc: accusative, d: dual, f: feminine, Gen: genitive, Impf: imperfective, Impr: imperative, Ind: indicative, Interro: interrogative, m: masculine, Mod: modal, Nom: nominative, NPI: negative polarity item, Nu: nunation, p: plural, Part: participle, pron: pronominal, Prog: progressive, Pst: past, s: singular, 12 3: $1^{\text {st }} 2^{\text {nd }}$ and $3^{\text {rd }}$ person.

\section{Background}

Like the other modern dialects of Arabic, OA differs from Classical Arabic (CA) to varying degrees in how sounds, morphemes, and words are combined, as well as in the sound inventory. Since this paper is not on the origin of OA or its relationship to CA, I will just assume that the two varieties are similar at least by virtue of belonging to the same language family, Semitic. ${ }^{\circledR}$ I will also assume with Ryding (2005:4) and Holes (2004a:5) that CA and SA are different only in terms of phraseology and vocabulary. Thus, for purposes of comparison and contrast, I will be referring to SA. (2)

\subsection{Oman's location and the current linguistic situation}

Glover (1988:1-2) states that the OA varieties emerged in the $2^{\text {nd }}$ century A. D. when some nomadic Arabian tribes migrated from central (Najd) and southern (Yemen) parts of Arabia eastward (to present-day Oman), seeking water. Oman's geography (surrounded by Persia, the Indian Subcontinent, east African coasts, and Arabia) shaped much of its history, which had implications for the varieties of Arabic and languages its people speak. Given the commercial and cultural contacts that the Omani Arabs established with other nations in

\footnotetext{
(1) On the relationship between the modern colloquial dialects of Arabic and CA, see Ferguson (1959), Holes (2004a), and Benmamoun \& Hasegawa-Johnson (2013).

(2) For an overview of the emergence, spread, and development of SA and the other modern dialects, see Watson (2002:6-9) and references therein. For an overview of the development of Arabic and views on when the modern varieties evolved as well as on their general characteristics, see Ryding (2005:1-6) and references therein.
} 
Arabia and the Indian Ocean, the Omani linguistic context became quite rich given the relatively small population of Oman; the November 2015 census speaks of 4,301,825 people, $44 \%$ percent of whom are expatriates. Besides OA, which is also spoken in Kenya, Tanzania, and parts of the United Arab Emirates (Al-Aghbari, 2004a:17), some Omanis speak a number of indigenous (Modern South Arabian) languages like Mehri and Jibbāli/Šahri (each with several thousand speakers), as well as Hobyōt, Baṭhari and Harsūsi (each with a few hundred speakers). In addition, some Omanis speak non-indigenous languages including Baluchi (from Baluchistan), Fārsi/Persian, Gajmi, Kumzāri (from Iran), Zidjāli (from Pakistan), Kojki/Luwāti (from India), and Swahili (from East Africa). Zanzibar and Baluchistan as well as parts of Kenya, Iran, and the United Arab Emirates were parts of the Omani Empire $\left(18^{\text {th }}-19^{\text {th }}\right.$ century). The vast majority of the native speakers of these languages also speak a variety of OA, and they have assimilated into the Omani society, and are now Omani citizens. Moreover, the non-Arabic speaking workforce speak at least one of these languages: Malayalam, Tamil, Kannada, Telugu, Hindi, Sindhi, Urdu, Punjabi, Sinhalese, Gujarati, Bengali, Tagalog, Korean, Thai, Nepalese, Chinese, and Indonesian, as well as English, French, German, and Dutch, on oil fields. The Arabic speaking expatriates speak other dialects of Arabic including Egyptian, Moroccan, Algerian, Tunisian, Sudanese, Iraqi, Yemeni, Lebanese, Jordanian, Syrian, and Palestinian. These non-indigenous languages as well as Arabic dialects, including SA, have caused changes in OA.

\subsection{Omani Arabic in contact with other dialects and languages}

OA has long been influenced by other languages. The coastal varieties were much different from SA due to centuries-long contact with merchants and settlers from foreign countries, like Persia and the Indian Subcontinent. Some of the interior dialects were also influenced by Swahili since the Omanis returning from Zanzibar settled in the interior, but this happened in the latter half of the last century. The linguistic changes in OA in the last four decades are due to contact with expatriates, Arabs and non-Arabs alike. The policies adopted by the Omani leaders prior to 1970 had isolated the Omanis from the rest of the (Arab) world. In 1970, a new regime with different policies came to power. These policies included, for the first time in Oman, open economy, large-scale education, health services, and media. Thus dialect change was also caused by education/literacy programs (run in SA) as well as by contacts with speakers of other dialects of Arabic who spread all over the country, working in schools and hospitals.

The booming economy caused many Omanis from the interior to move to the coastal 
areas, especially the Capital area, to take advantage of the available economic opportunities. This resulted in changes in the interior dialect to conform to the coastal one, this being the variety of the majority, as well as in the coastal one being influenced by that of the new comers, both interior people and expatriates. The school teachers came from different Arab countries, which exposed the Omani youngsters to other Arabic dialects as well as to SA outside the mosque. Furthermore, exposure to SA in the media resulted in OA gaining some new vocabulary and losing some of the old words used by older generations, like Srūq 'blood vessels' which was replaced with šarāyinn $w$ Pawridah 'arteries and veins'. Moreover, Holes (1989:449) states that the educated generations of Oman follow Gulf dialect tendencies like replacing feminine plurals with masculine ones, and also replacing the internal passive (section 4.8) with the /in/-passivizing prefix, as in y-in-ktib 'it is (being) written' instead of yi-ktab. This is seen most vividly in the Capital area as well as in the media (Holes, 2014), where expressions like Gulf-coast tšs̆h 'like this' and San jadd 'seriously' are common. Although SA is the official language of Oman that is used in mass media, official ceremonies, public and religious speeches, as well as education and government written transactions, very few people learn it before school, in some educated households and mosque (QurPān) schools.

Shaaban (1977:11) states that "the linguistic contacts with Indians, Persians, Baluchis, and Africans have left traces in the speech of Omani Arabs, especially in the vocabulary. These foreign languages left phonological, morphological, and syntactic traces as well in the Arabic speech of the members of those foreign communities, creating communal dialects based on ethnic background rather than on religion or race". The effect of these languages on OA is most vividly seen in the vocabulary, with borrowings like güniyyah 'sack' and bigli 'electrical torch' from Hindi, drī̌sah 'window' and sāmān 'stuff' from Persian, sēkal 'bicycle', batri/bētri 'battery', swīk 'switch', and bēb 'pipe' from English, and bandèrah 'flag' and $m \bar{e} z$ 'table' from Portuguese (Holes, 2014:9-10); the Portuguese occupied some coastal Omani towns between 1507-1624. The Swahili words in OA are food item names, like mandāzi 'buns'. OA assigns these borrowings either sound feminine or broken plural forms.

The following table provides the plural forms assigned to these borrowings. Monosyllabic words receive sound feminine plural forms, and bi-syllabic words receive broken plural forms. Tri-syllabic words may follow either pattern.

Table 1. Plural Forms Assigned to the Borrowings

\begin{tabular}{|c|l|l|l|}
\hline \hline & Language Borrowed from & Singular and Meaning & Plural Form \\
\hline 1 & English & bēb 'pipe' & bēb-āt \\
\hline
\end{tabular}


Rashid Al-Balushi

\begin{tabular}{|l|l|l|l||}
\hline 2 & English & swīk 'switch' & swīk-āt \\
\hline 3 & English & sēkal 'bicycle' & sayākil \\
\hline 4 & English & batri and bētri 'battery' & batāri \\
\hline 5 & Hindi & gūniyyah 'sack' & gawāni \\
\hline 6 & Hindi & bigli 'torch' & bagāli \\
\hline 7 & Persian & drīšah 'window' & darāyiš \\
\hline 8 & Persian & sāmān 'things/stuff' & \\
\hline 9 & Portuguese & bandērah 'flag' & bandērāt \\
\hline 10 & Portuguese & mēz 'table' & mēzāt \\
\hline \hline
\end{tabular}

Glover (1988) notes that the overall development (oil industry, introduction of automotives, construction, etc.) that Oman witnessed introduced into OA words from other languages, mainly English, and, conversely, the extensive exposure to SA resulted in replacing words borrowed from other languages by ones from SA. These include kandēšan 'air conditioner', which was later replaced with mkayyəf, mōtar 'car', which was later replaced with siyyārah, ?ōtēl 'restaurant', which was later replaced with maţGam, and $\hbar a f i s$ 'office', which was later replaced with maktab.

Besides being a lingua franca that the minority language speakers use for communication, OA, with various dialects (to be discussed in the next section), is used for the documentation of popular folklore and poetry. For the last four decades, besides being widely used in commercial transactions, which usually involve non-Arabs, as well as being the only foreign language taught in public schools, English has been another lingua franca in Oman.

\subsection{The Omani dialects of Arabic}

The literature on the OA dialects consists mainly of descriptive and sociolinguistic accounts carried out by orientalists, grammarians, sociolinguists, and interested foreign personnel. The OA dialects that have been examined include the Muscat dialect (Praetorius, 1880; Jayakar, 1889; Shaaban, 1977; Glover, 1988; Al-Aghbari, 2004a), the Musandam dialect (Jayakar, 1903), the Dhofāri dialect (Rhodonakis, 1908, 1911), the Al-Buraimi dialect (Johnstone, 1967), the interior sedentary dialect (Reinhardt, 1894; Galloway, 1977), the Al-Xābūrah dialect (Brockett, 1985), the Al-Ristāq dialect (Prochazka, 1981), the $\bar{A}$ l-Wahība Bedouin dialect (Webster, 1991), a Šawāwi (nomadic pastoralists in the northern mountainous interior) dialect (Eades, 2009a), and the Bedouin dialect of the Hidyīwī tribe in Al-Mudaybi (Eades, 2009b). Besides, Clive Holes' various writings (e.g. 1989, 1991, 1996, 1998, 2004b, 2007, 2011, 2012, 2013, 2014) investigate and document 
various linguistic properties of OA.

Shaaban (1977:12) states that "the most important sociolinguistic distinction holds between coastal and interior OA" dialects, which coincides with the sedentary vs. Bedouin distinction. This criterion, nonetheless, he notes, has failed to stand the test of time as a result of dialect change. Holes (1989) proposes that the OA dialects spoken in northern and central Oman can be classified into four major varieties, two Bedouin, further divided into Bedouin 1 and Bedouin 2, and two Haḍari or sedentary, further divided into Haḍari 1 and Hadari 2. Holes' division does not include the dialects spoken in Muscat (the Capital area) and Dhofār (southern Oman). He states that while the Hadari/sedentary dialects are spoken in "the towns and villages in and around the mountain massifs of the Jabal Akhdar and Eastern Hajar", the Bedouin dialects are spoken by "the Badu nomadic or semi-settled populations of the western desert, the Jaddat al-Harāsīs, and Wahība Sands" (p. 447). He though states that this "mountain/desert dialect distinction, within which there are important subdialects is not always clear-cut: there are transitional areas where the population is a mix of Hadar and Badu groups, and in which both dialect types, or a 'mixed' dialect, can be heard" (p. 447). A good example of such an area is the Bāṭina coast, which is inhabited by speakers of Bedouin dialects (e.g. Al-Yałmadi, Al-Mālki, Al-Whībi, and Al-Mbēhsi tribes, originally from eastern Oman), where the people refer to themselves as Badu, and also based on certain linguistic variables. It is also inhabited by speakers of

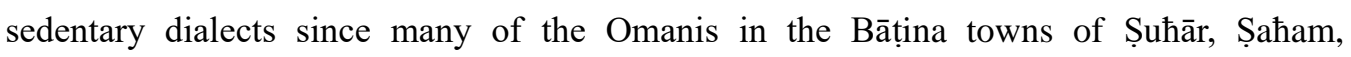
Al-Xābūrah, and Al-Suwaiq descend from the northern mountains (e.g. Al-Bādi, Al-Miqbāli, Al-hōsni, and Al-Mąmari tribes). There are also Omanis who originally came from Persia or the Indian subcontinent; these tribes are Al-Balūshi, Al-Fārsi, Al-ৎajmi, and Al-Luwāti. This is also the case in another two Bāṭina towns, Barkā and Al-Mușunfah. These mixed areas result from "the longstanding contact between the $\mathrm{H}$ [sedentary] people of the mountains, and the mixed population of the coastal region. Permanent and semi-permanent immigration into the lusher coastal areas from the coastal hinterland and the mountains has been going on for many generations" (Holes, 1989:452) ${ }^{1}{ }^{1}$ Indeed, Holes (2007:1) states that the "Bāṭina coast is a 'mixed' area where both types of dialect are encountered". This variation also results from 'transitional' systems which Holes observes

\footnotetext{
(1) As for the other two towns on the Bāṭina coast, Luwa and Šināṣ, I think they are (mainly) Bedouin dialect areas. Even the population segments that have descended from the northern mountains speak a Bedouin dialect. This is probably because they have been in the coastal area for a long time, and also because of the socioeconomic contacts and relations with the UAE people, most of whom speak Bedouin dialects.
} 


\section{Rashid Al-Balushi}

in Ibrā and Al-Kāmil at the northern edge of the Wahība Sands, where the speakers have preserved the SA /q/ (a feature of sedentary dialects), but, due to contact with Bedouins, have replaced /g/ with /y/, see Eades (2011) for a report on a transitional dialect in northern Oman. Also, many of the communities have settled down and the dialects have been influenced by other OA and Arabic dialects. This shows that the OA dialects are merging, which calls for investigation and documentation of their properties before these are lost in the process of modernization.

According to Holes, the two Bedouin dialect types have the same syllable structure, and the two sedentary ones share the same syllable structure. However, each of the four dialect types behaves differently in terms of how they realize the SA consonants /q/, /k/, and / $/$ / $(\mathrm{p}$. 449-452). Besides these two phonological variables, there are four morphological variables. First, while the Bedouin varieties have $y \bar{a}$ - as the imperfective prefix, as in $y \bar{a}-k i l$ 'he eats', the sedentary varieties have $y \bar{o}$ - (or $y \bar{u}$-), as in $y \bar{o}$-kil (or $y \bar{u}-k i l$ ). Second, while the Bedouin varieties have $-\bar{u} n$ and $-\bar{l} n$ for plural and singular feminine suffixes, as in $y \bar{a}-k l-\bar{u} n$ 'they.m eat' and $t \bar{a}-k l-\bar{i} n$ 'you.sf eat', the sedentary varieties have $-u$ and $-i$, respectively, as in $y \bar{o}-k l-u$ and $t \bar{o}-k l-i$. Third, the object and possessive suffix in the Bedouin dialects is $-a h$, as in $y$-kitb-ah 'he writes it' and ktäb-ah 'his book', but it is -uh (or -oh) in the sedentary varieties, as in $y$-kitb-uh and ktäb-uh. Fourth, the first person plural prefix is nti- in the Bedouin dialects, as in nti-xabbar 'we ask', but it is nit- in the sedentary dialects, as in nit-xabbar. The division also points out dialectal similarities between the four types and other Arabic dialects spoken in the Arabian penisula.

While I accept Holes' classification of Omani dialects (as Bedouin and sedentary), I would like to stress his observation that each type, Bedouin vs, sedentary, comprises more than one variety. Therefore, I will assume that there are various dialects that could go under each dialect type. Thus, the OA sedentary varieties include the Bățina sedentary dialect, the northern Oman sedentary dialect (in the northern mountains and valleys, Jabal Paxdar), and the Dhofāri sedentary dialect (in the towns and mountains, similar to the bordering Yemeni one). The Bedouin varieties include the eastern Bedouin dialect (spoken in Șūr), the western Bedouin dialects (similar to those of southern Najd), the northwest and southeast Bedouin dialects (similar to those spoken on the Gulf coast), and the Dhofări Bedouin dialect. As for the dialect spoken in the Musandam peninsula (farthest north), Šiћii, I think it is a mixed dialect, spoken in sedentary communities (mountains, valleys, and coasts), but shares properties with the Bedouin dialect spoken in the UAE. The variety spoken in the Capital area (Muscat) is mainly sedentary, but Bedouin varieties are also encountered as the 
population of Muscat is mixed. As Holes (1989:447) notes, the topography of Oman (mountains, deserts, coasts, plains) suggests dialectal variation. Besides these OA varieties, there has also developed a pidgin as a means of communication between the OA speakers and the non-Arabic speaking expatriates, especially those from the Indian Subcontinent. This pidgin is characterized by simplified word and clause structure and vocabulary taken from Arabic, English, Hindi, and Urdu. Most of the data and discussion will be based on the Bățina sedentary dialect (BSD), the Dhofäri sedentary dialect (DSD), and the Muscat dialect (MD). The following sections survey various phonetic, phonological, morphological, and syntactic aspects of the OA dialects spoken in the 61 towns and cities of Oman, each with several villages and neighborhoods. ${ }^{(1}$

\section{Phonetics}

\subsection{Consonants}

The various OA dialects have the 29 consonants in table 2 (Shaaban, 1977:35; Glover, 1988:37; Al-Aghbari, 2004a:25; Holes, 2007:2). The SA forms will be in parentheses, and phonetic transcription will be in brackets.

Table 2. OA Consonants

\begin{tabular}{|c|c|c|c|c|c|c|c|c|c|}
\hline & Bilabial & Labiodental & Dental & Alveolar & Palatal & Velar & Uvular & Pharyngeal & Glottal \\
\hline Stops & $\mathrm{b}$ & & & $\begin{array}{ll}\mathrm{t} & \mathrm{d} \\
\mathrm{t} & \end{array}$ & & $\begin{array}{ll}\mathrm{k} & \mathrm{g}\end{array}$ & $q$ & & $?$ \\
\hline Fricatives & & f & $\begin{array}{ll}\theta & \partial \\
& \partial \underset{ }{\theta}\end{array}$ & $\begin{array}{l}S \\
S\end{array}$ & š & & $\begin{array}{ll}\mathrm{x} & \mathrm{y}\end{array}$ & $\hbar$ & h \\
\hline Affricates & & & & & $\check{c} \quad \check{\mathrm{j}}$ & & & & \\
\hline Nasals & $\mathrm{m}$ & & & $\mathrm{n}$ & & & & & \\
\hline Lateral & & & & 1 & & & & & \\
\hline Trill & & & & $\mathrm{r}$ & & & & & \\
\hline Glides & $\mathrm{w}$ & & & & $y$ & & & & \\
\hline
\end{tabular}

2.1.1 The emphatics

The SA /ọ/, /ș/, and /ț/, the so-called emphatic (pharyngealized or velarized) consonants, are retained in all the OA dialects. The SA voiced alveolar emphatic stop / $\mathrm{d} /$ is available in

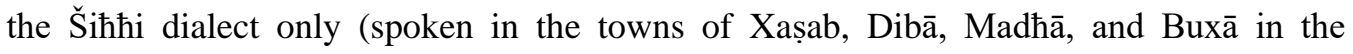

\footnotetext{
(1) It is worth mentioning that Muscat is the name of both the Capital city and the Capital governorate/area, the latter includes other cities and towns.
} 


\section{Rashid Al-Balushi}

Musandam peninsula), and occurs in free variation with /ọ/ and /ẓ/, the latter not available elsewhere in OA. In the town of Xașab variety, /ḍ/ appears in SA words with /ḍ/, as in darab 'hit' (daraba), as well as in SA words with /ợ/, as in dalom 'darkness' (ð̣aläm) and

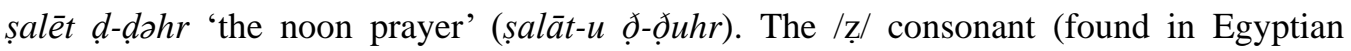
Arabic) is also heard in this dialect replacing /ọ/ and /ḍ/, so one can hear some native

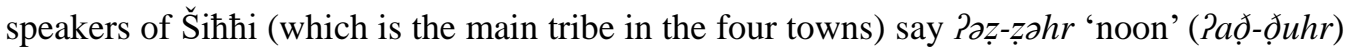
and Paz-zayt 'blood pressure' (?ad-dayt). The variety spoken in the town of Dibā has the /ọ/ sound, so one can hear șalät $\partial$ - $\partial \partial h r$ 'the noon prayer'. In all the other OA dialects, /d / is replaced with /ọ/.

\subsubsection{The glottal stop}

Like other modern Arabic dialects, most OA dialects have largely lost the glottal stop word-initially. For example, the imperative verb in all the OA varieties has lost the prefix ?V- of SA (?u- or ?i-). Holes (2007) also mentions examples of / $/$ / in initial position being replaced with /w/, as in waxxər 'go out of the way!' and wakkad 'to be certain of/to know well' (but ?axxar 'to postpone' and Pakkad 'to confirm' also exist in some sedentary varieties), as well as with /y/, as in yadab 'discipline/manners' (?adab) and yāl 'offspring of' (?āl SaSd 'offspring of SaYd'). Most OA dialects preserve the glottal stop word-initially in contexts like the $1^{\text {st }}$ person verb forms, as in ?a-qūl 'I say' and $? a-r \bar{r} d$ 'I want', but dropped it in the $2^{\text {nd }}$ person pronouns, so they have ntah 'you.sm' (?anta). Some sedentary varieties (both in Jabal Paxḍar mountains and Bāṭina) have preserved the glottal stop word-initially in certain words, like Pumūr/Pamūr 'matters' and Pašya 'things'.

Except for borrowings from SA, like tra??as 'chaired (a meeting)', the OA dialects have also lost the glottal stop word-medially and replaced it with either vowel length, as in $r \bar{a} s$ 'head' ( $r a$ ? s), fās 'axe' ( $f a$ ? s), and yākil 'he eats' (ya-?kul), which applies in most dialects, or $/ y /$, as in wrāyak 'behind you' (SA warā?ak) in DSD. In other dialects, the glottal stop is completely lost, as in warāk 'behind you'.

This replacement of the glottal stop with vowel length word-medially is also observed in some readings of the Holy Qur?ān, like that of Warš (by way of Nāfi@), as the verses in

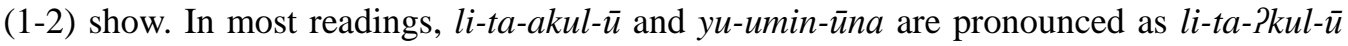
and $y u$-?min-üna, respectively. Vowel length is achieved by adding a short vowel, $a$ or $u$, identical to the already available short vowel in the prefix, $t a$ - and $y u$-, respectively. The verse in (2) also shows a case of glottal stop loss word-medially; bi-l-äxirat-i is pronounced as bi-l-?āxirat-i in most readings.
(1) wa
huwa 1-laðī
saxxara
1-baћr-a 


\section{Omani Arabic: More than a Dialect}

\begin{tabular}{|c|c|c|c|}
\hline and & the-who & Pst.subject. $3 \mathrm{sm}$ & the-sea-Acc \\
\hline li-ta-akul-ū & $\min -\mathrm{hu}$ & laћm-an & țariyy-ā \\
\hline so-2-eat-pm & from-it & meat-Acc & fresh-Acc \\
\hline
\end{tabular}

'It is He Who has made the sea subject, that you may eat thereof flesh that is fresh and tender ...'

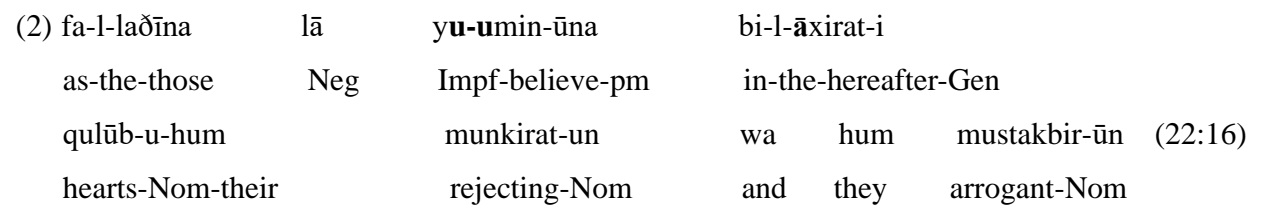

'As to those who believe not in the Hereafter, their hearts refuse to know, and they are arrogant.'

Similarly, except for borrowings from SA, like ?ahyā? 'biology', the glottal stop is largely lost word-finally where it is realized as /y/ or /w/, as in $m \bar{a} y$ 'water' ( $m \bar{a}$ ? $)$ and ðaww 'fire' (daw?), as well as in verbs where the third radical is a glottal stop (hamzated),

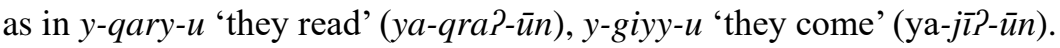

\subsubsection{The reflexes of /q/}

While the Bedouin dialect speakers pronounce /q/ as /g/, as in $y$-gūl 'he says' (ya-qūl-u) and gașìrlgașīr 'short' (qașīr), the speakers of DSD (Șalālah city) and some Bātina varieties (e.g. the center of Șohār city), as well as other sedentary dialect speakers,

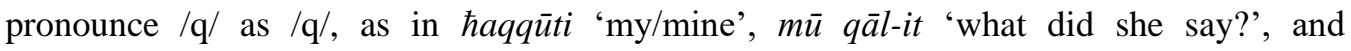
yi-twahhaq 'he gets into trouble'. Speakers of sedentary dialects spoken in and around the northern mountains pronounce /q/ as $/ \mathrm{k} /$, as in $m \bar{u} t-k \bar{u} l$ 'what are you.sm saying?' ( $m \bar{a} \partial \bar{a}$ ta-qūl-u) and kahwah 'coffee' (qahwah). Holes (2014) states that /q/ is pronounced as / $/ \mathbf{j} /$ in

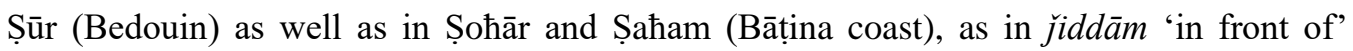
(quddām) and juirīb 'near' (qaī̄b).

Based on personal observation, /q/ is also pronounced as $/ \gamma /$ in Șūr, as in yara 'read' (qara?a) and yaryah 'village' (qaryah), this also happens in some Kuwaiti Arabic varieties, as in yərš 'shark' (qirš), as well as in Sudanese Arabic, as in Panayyil 'I move' (?u-nqqil-u). Many of the eastern dialect speakers (Bedouin) as well as those of the dialect spoken in the mountains of Dhofār pronounce / / / as /q/, as in qurāb 'crow' (zurāb) and qazāl 'gazelle' (yazāl) from Dhofār and $2 a-b q i$ 'I want' (?a-byi), qāli 'expensive' ( $(a \bar{a} l i)$, and qarīb 'stranger' (yarīb) from Șūr. Glover makes similar observations about /q/ and / $/ \mathrm{f} /$ in MD (p. $39)$.

\subsubsection{The palatal affricates}

The voiced palatal affricate $/ \mathbf{j} /$ of SA is available in some OA dialects, mainly Bedouin, as in Al-Buraimi, Șūr, Șoћār, and Șaham (section 2.1.3). It also appears in some northern 


\section{Rashid Al-Balushi}

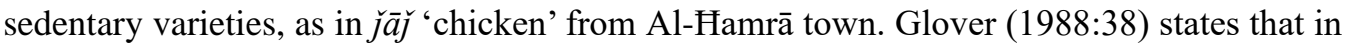
MD "the voiced palatal affricate $/ \tilde{j} /$ is a free variant of $/ \mathrm{g} /$ in most words", but that $/ \mathrm{j} /$ is starting to be restricted to speech with foreigners (sophisticated/educated) and for borrowings from SA. As for most dialects, $/ \mathfrak{j} /$ is replaced with the velar stop $/ \mathrm{g} /$.

The voiceless palatal affricate, /č/, which is not available in SA, is heard in loanwords, like lanč 'motorboat', as well as in the Al-Buraimi dialect, replacing $/ \mathrm{k} /$, as in $b \bar{a} c ̌ a r$ 'tomorrow' (bākir). This phenomenon is referred to as kashkasha; see Holes (1991). ${ }^{(1)}$ Holes (2014) states that the Al-Buraimi dialect (west) as well as the Șūr and JaYlān ones (east), all Bedouin, have /č/ replacing /k/, as in simač 'fish' (samak) and čiswəh 'bride's clothes' (kiswah); this, however, does not apply to all Bedouin dialects in Oman, certainly not the one in Dhofār (south). He also provides examples of /č/ in Wādi Sahtan (sedentary),

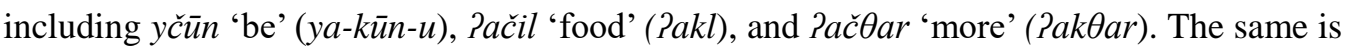
found in the nearby town of Al-Hamrā, in which Al-乌abri tribe people say čêčah 'cake'

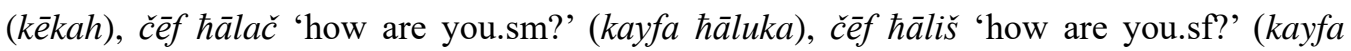
$\hbar \bar{a} l u k i)$, and dəččān 'shop' (dukkān), whereas Al-Șubћi tribe people, in the same town, pronounce 'cake' as keekk. Thus /č/ seems to be used in free variation with /k/. Nonetheless, while this affrication (from $/ \mathrm{k} /$ to $/ \check{c} /$ ) occurs in the Bedouin dialects in the vicinity of front vowels, it is unconditional in the sedentary dialects (Holes, 2013).

\subsection{Vowels}

The vowel phonemes of OA are in table 3. Unlike SA, which has 6 vowels only, OA also has $/ \overline{\mathrm{o}} /$ and $/ \overline{\mathrm{e}} /$. These long mid vowels have historically been derived from diphthongs (Shaaban, 1977; Glover, 1988; Holes, 2007); thus bēt and lōn have come from bayt 'house' and lawn 'color', respectively. Al-Aghbari (2004a:27) also proposes that "both mid round vowels /o:/ and / $/: /[/ \overline{0} /$ and $\bar{\jmath}]$ are possible and can occur in free variation".

Table 3. OA Vowels

\begin{tabular}{|l|c|c|c|c|c|c||}
\hline \multirow{2}{*}{} & \multicolumn{2}{|c|}{ Front } & \multicolumn{2}{c|}{ Central } & \multicolumn{2}{c|}{ Back } \\
\cline { 2 - 7 } & Short & Long & Short & Long & Short & Long \\
\hline High & $\mathrm{i}$ & $\overline{\mathrm{i}}$ & & & $\mathrm{u}$ & $\overline{\mathrm{u}}$ \\
\hline Mid & & $\overline{\mathrm{e}}$ & & & & $\overline{\mathrm{o}}$ \\
\hline
\end{tabular}

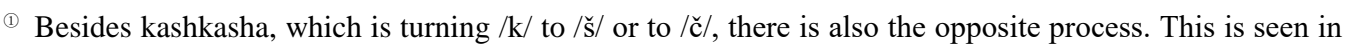
BSD words like külah 'kerosene camp stove', which is šölah in the Indian Pidgin as well as in DSD, and which refers to šuSlah 'fire torch' in SA. Examples also include $k \bar{a} h i$ 'tea' (in some BSD varieties), which is $\breve{s} \bar{a} h i$ in other OA dialects including DSD, and $\check{s} \bar{a} y$ in SA; also there is kabāte, which is čabāti 'bread' in Hindi. This process also applies to borrowings from English, as in lank 'lanch', swīk 'key/switch', and sandawīkah 'sandwich'.
} 
Omani Arabic: More than a Dialect

\begin{tabular}{|l|l|l|l|l|l|l||}
\hline Low & & & $\mathrm{a}$ & $\overline{\mathrm{a}}$ & & \\
\hline
\end{tabular}

Shaaban (1977:43-44) and Holes (2007) discuss the allophones of these phonemes. The vowel /u/ has two more allophones, [ ], which occurs in unstressed syllables, as in yi-ktub [yi-ktub] 'he writes' and kurfāyah [korfāyah] 'bed', and a lower one occurring in the vicinity of emphatic sounds, which is [o], as in tubb [tobb] 'magic/superstition' and șubb [șobb] 'pour!'; [u] occus in words like kull 'all', as pronounced in DSD.

As for $/ \mathrm{a} /$, it seems to have different variants in different environments. Next to emphatics, this vowel is realized as a low back variant [a], as in marað̆ [mạ̦ạ̣] 'to become sick' and talab [țalab] 'request'; the emphasis even reaches /1/. When flanked by laryngeals ( $\mathrm{h}, \mathrm{C}, \mathrm{P}$, and $\mathrm{h}$ ) and uvular /q/, it is realized as a slightly different low back variant [a], as in Saraq [Saraq] 'sweat', ћaraq [haraq] 'he burnt (something)', and qalam [qalam] 'pen'. The elsewhere variant is the low front/central [æ], shorter than the English counterpart, as in ganb [gæmb] 'side' and kalb [kælb] 'dog'.

There is also the tendency of replacing /a/ with the mid-front variant [e] in word-final position when not preceded by emphatics or uvulars. Examples include baSad-na [baSadne] 'after us', Pahal-na [?ahalne] 'our relatives', and kürat-ha [kūrat-he] 'her ball'. This also applies to country names that end in /a/ in SA, like lỉbye (Lībya), kīnye (Kīnya), and rūsye (Rūsya). Holes (2007) discusses this tendency (known as Pimālā) and states that /a/ may even be replaced with [i] in this context, as in mistašfi 'hospital' (SA mustašfāa, and OA

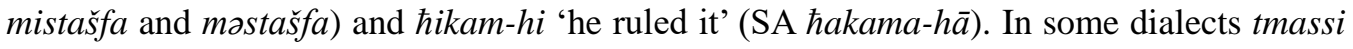

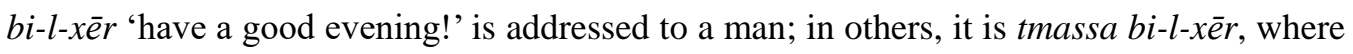
tmassi bi-l-xer is addressed to a woman. This is common in Bedouin and sedentary dialects in Bāṭina.

This Pimālā phenomenon found in some OA varieties is also witnesed in some readings of Holy Qur?ān, as in the verse in (3), according to the reading of Xalaf (by way of Hamzah), and the verse in (4), according to the reading of Hafș (by way of Yāșim). Other readers pronounce 'qalē' in (3) as 'qalā'; in other SA contexts, 'majrē-hā' in (4) is pronounced as 'majrā-hā'.

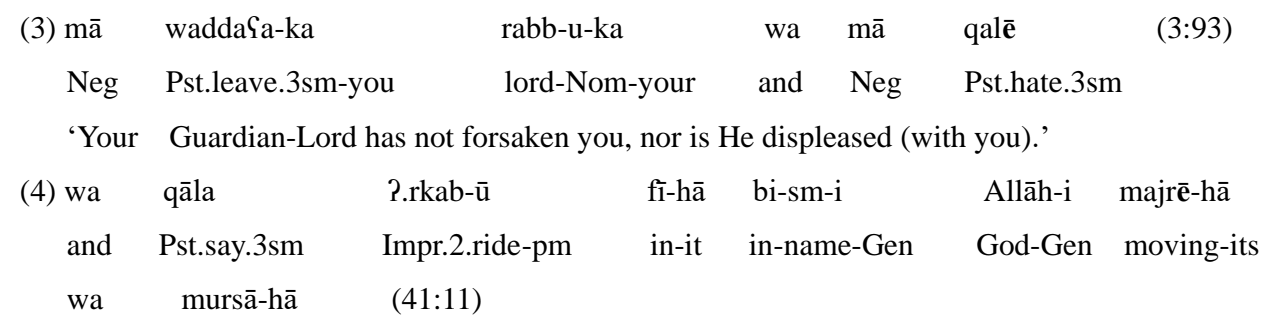




\section{Rashid Al-Balushi}

and at.rest-its

'So he [Noah] said: "Embark you on the Ark, In the name of Allah, whether it move or be at rest! ..."

Likewise, /i/ is realized as retracted [I] in medial position, as in bint [bInt] 'girl', and gimbi [gImbi] 'my side' in DSD. In word-final position, it is the close front [i], as in bêti [bēti] 'my house'. Holes also states that "before /b, m, f, r, q/ and the emphatics, particularly when these are in final position, it is backed and (with the labials) rounded, e.g. [za:hob] "ready" (p. 3). While this is true of the sedentary varieties in and around the Capital area, it is realized as /ə/ or even /i/ in other sedentary varieties, especially those in Bāțina; the same word may be heard as [za:həb] or [za:hib]. In and around the Capital area, one hears proper names like SA ৎāmir and Sālim as [Cāmor] and [sālom]; in other parts of the country, they are heard as [ৎāmər] and [sāləm] or even [ৎāmir] and [sālim].

Besides backing, emphatics (as well as $/ \mathrm{r} /$ and uvulars) lower $/ \overline{\mathrm{u}} /$ to $/ \overline{\mathrm{o}} /$, when in the same syllable. So the SA $s \bar{u} q$ 'market' is $s \underline{o} q$ in MD (Glover, 1988:55); $s \bar{o} q$ is also heard in DSD. However, in Bāṭina, one can hear $s \bar{u} q$ and $s \bar{o} q$ (as in Șohār), sūg (as in all coastal communities, Bedouin), and both sūk and sōk (by speakers originally descending from northern mountains). Emphatics also lower $/ \overline{1} /$ to $/ \overline{\mathrm{e}} /$, as in $y$-șē 'he cries' and $y$-țē 'he falls down', this is not an effect of the guttural $/ \hbar /$, since this lowering also happens in $y$-țér 'he flies' and $y$-șer 'it works'. Finally, [ə] is a possible variant in different dialects for all three short vowels when they are in unstressed syllables (Shaaban, 1977:44).

\section{Phonology}

\subsection{Syllable structure}

Syllables in OA must begin with a consonant. With the exception of / $/$, any consonant may occur syllable-initially, -medially, or -finally. Syllables with three consonants in the onset may occur word-initially, as (11-12) in table 4 show, but never word-medially or -finally (Al-Aghbari, 2004a:31). In word-medial position, a single consonant is syllabified with the following syllable, thus katab 'write' is syllabified as ka\#tab. However, a word-medial cluster of two or three consonants is broken such that only one consonant is left for the onset of the following syllable (Glover, 1988:59). While Glover's example for a medial cluster of two consonants, gar\#gūr 'shark', is good for the case since OA has syllables where $/ \mathrm{r} /$ is followed by $/ \mathrm{g} /$, as in $\mathrm{rga}$ S 'come back!', her example of a cluster of three consonants, xubz\#ha 'her bread', may be accounted for based on the fact that the accepted syllable boundary is also a morpheme boundary; the same applies to bint\#kum 
'your.pm daughter'.

While geminates may occur word-medially, as in ћassab 'think', they do not occur word-finally except in active participial forms, as in mādd 'extending' and lāmm 'gathering'. Their occurrence in word-initial position is usually a result of assimilation, as in $l+r \bar{a} \mathrm{~s}$ 'the head' becoming $r r a \bar{a} s$, and $l+t \partial f f a \bar{\hbar} a h$ 'the apple' becoming ttaffähah. OA has the syllable types illustrated in table 4, from Shaaban (1977:45) and Holes (2007:3). The types 6-11 occur only word-initially. Shaaban states that form (12) is restrictive, occurring only with the stated consonants in the onset. Similarly, the form in (13) is restricted to the active participle form of geminate verbs. These syllable forms are allowed in OA as a collection of dialects; each variety exhibits some or all of them.

Table 4. OA Syllables

\begin{tabular}{|c|c|c|c|c|c|}
\hline & Syllable Shape & Free Form & Word-initial & Word-medial & Word-final \\
\hline 1 & $\mathrm{CV}$ & & $\begin{array}{l}\text { qa\#rūh } \\
\text { 'they read it' }\end{array}$ & $\begin{array}{l}\text { maț@ia\#mak } \\
\text { 'your restaurant' }\end{array}$ & $\begin{array}{l}\text { bē\#ti } \\
\text { 'my house' }\end{array}$ \\
\hline 2 & $\mathrm{CVC}$ & $\begin{array}{l}\text { kil } \\
\text { 'eat!' }\end{array}$ & $\begin{array}{l}\text { laS\#bu } \\
\text { 'they played' }\end{array}$ & $\begin{array}{l}\text { sā\#\#baq\#hum } \\
\text { 'he raced them' }\end{array}$ & $\begin{array}{l}\text { ktā\#bak } \\
\text { 'your book' }\end{array}$ \\
\hline 3 & CVCC & $\begin{array}{l}\text { harb } \\
\text { 'war' }\end{array}$ & $\begin{array}{l}\text { šuft\#hum } \\
\text { 'I saw them' }\end{array}$ & \begin{tabular}{|l} 
ḍa\#rabt\#na \\
'you have hit us'
\end{tabular} & $\begin{array}{l}\text { ka\#bart } \\
\text { 'I have grown up' }\end{array}$ \\
\hline 4 & $C \bar{V}$ & $\begin{array}{l}\text { mū } \\
\text { 'what?' }\end{array}$ & $\begin{array}{l}\text { gā\#llis } \\
\text { 'he is sitting' }\end{array}$ & $\begin{array}{l}\text { qa\#rū\#ha } \\
\text { 'they read it' }\end{array}$ & $\begin{array}{l}\text { rā\#nū } \\
\text { 'they went', }\end{array}$ \\
\hline 5 & $\mathrm{C} \overline{\mathrm{V}} \mathrm{C}$ & $\begin{array}{l}\text { rāh } \\
\text { 'he went' }\end{array}$ & $\begin{array}{l}\text { sēf\#hum } \\
\text { 'their sword' }\end{array}$ & $\begin{array}{l}\text { bat\#rūћ\#loh } \\
\text { 'she will go to him' }\end{array}$ & $\begin{array}{l}\text { bat\#sīr } \\
\text { 'will you go?' }\end{array}$ \\
\hline 6 & $\mathrm{CCV}$ & $\begin{array}{l}\text { mša } \\
\text { 'he went/walked' }\end{array}$ & $\begin{array}{l}\text { šta\#yal } \\
\text { 'he got a job' }\end{array}$ & & \\
\hline 7 & $\mathrm{CCVC}$ & $\begin{array}{l}\text { ợub } \\
\text { 'hit!' }\end{array}$ & $\begin{array}{l}\text { htar\#rit } \\
\text { 'it got hot' }\end{array}$ & & \\
\hline 8 & $\mathrm{CC} \overline{\mathrm{V}}$ & $\begin{array}{l}\text { mš̄̄ } \\
\text { 'walk!' }\end{array}$ & $\begin{array}{l}\text { mqā\#bar } \\
\text { 'grave yards!' }\end{array}$ & & \\
\hline 9 & $\mathrm{CC} \overline{\mathrm{V}} \mathrm{C}$ & $\begin{array}{l}\text { blād } \\
\text { 'a country' }\end{array}$ & $\begin{array}{l}\text { ștāab\#it } \\
\text { 'she got sick' }\end{array}$ & & \\
\hline 10 & CCVCC & $\begin{array}{l}\text { ћtart } \\
\text { 'I was confused' }\end{array}$ & $\begin{array}{l}\text { xtart\#ha } \\
\text { 'I chose it' }\end{array}$ & & \\
\hline 11 & CCCVC & štyil & stlum\#ha & & \\
\hline
\end{tabular}


Rashid Al-Balushi

\begin{tabular}{|c|c|c|c|c|c|}
\hline & & 'work!' & 'receive it!' & & \\
\hline 12 & $\mathrm{stC} \overline{\mathrm{V}} \mathrm{C}$ & $\begin{array}{l}\text { stqām } \\
\text { 'it straightened' }\end{array}$ & $\begin{array}{l}\text { strāh } \\
\text { 'he rested' }\end{array}$ & & \\
\hline 13 & $\mathrm{C} \overline{\mathrm{V}} \mathrm{CC}$ & $\begin{array}{l}\text { rādd } \\
\text { 'returning', }\end{array}$ & $\begin{array}{l}\text { rādd l-bēt } \\
\text { 'returning home' }\end{array}$ & & \\
\hline
\end{tabular}

3.2 Word stress

Shaaban (1977:77) states that "stress in OA is fixed and predictable". It falls on the long syllable in a word, where a long syllable is one with a long vowel followed by at least one consonant $(\mathrm{C} \overline{\mathrm{V}} \mathrm{C})$, or one with a short vowel and at least two consonants in the coda (CVCC). Thus the first syllable is stressed in kā́t\#bah 'she is writing' and zấr\#hum 'he has visited them', whereas the second is stressed in ka\#tábt 'I have written' and xab\#bárt 'I have informed (someone)'. If a word is mono-syllabic, whether the syllable is long, like šayy 'thing', or short, like min 'from', stress falls on that single syllable/vowel, resulting in šáyy and min. If a word is bi-syllabic and both syllables are long, stress falls on the second

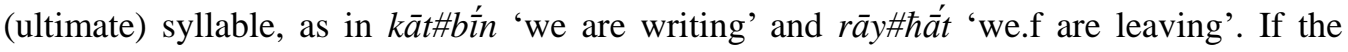
bi-syllabic word has no long syllables, then stress falls on the first (penultimate) syllable, as in mág\#mar 'incense burner' and ká\#tab 'he has written'. If a word is poly-syllabic with one long syllable, then that syllable is stressed, as in ợ\#rábt\#na 'you have hit us' and da\#šă\#dì̌šnhum 'their clothes'. If the poly-syllabic word has no long syllables, like már\#ka\#bak 'your boat', bá\#ra\#kah 'a blessing', and sá\#ma\#kah 'a fish', then stress falls on the antepenultimate syllable. As Holes (2007:4) observes, such forms are reduced by deleting the second vowel, resulting in bi-syllabic ones, márk\#bak, bár\#kah, and sám\#kah, respectively.

\subsection{Phonological processes}

This section discusses examples of assimilation, spread of emphasis, metathesis, and ablaut. As Holes (2007:4) points out, all the OA dialects behave like SA with regard to assimilation of the /l/ of the definite article (?al-) to the first consonant in the noun, this also applies to adjectives. Thus, the definite of gdìd 'new' is $P i l$-gdìd (or lo-gdìd), and the definite of $\check{s} a m s$ 'sun' is $2 i \check{s}$-šams. In this regard, OA behaves differently from Egyptian Arabic where the defintie of gidìd 'new' is Pig-gidìd, and the definite of kalb 'dog' is Pik-kalb. Another interesting tendency he mentions is the assimilation of the $/ \mathrm{h} / \mathrm{of}$ the feminine possessive pronoun - $h a$ to the $/ \mathrm{t} /$ in the nominal form. While in most OA dialects 'its price' is qìmit-ha, it is qìmat-te (or qìmat-ta, or even gìmat-te) in some Bātina Bedouin varieties, the same applies to ?axat-ha 'her sister' which is pronounced as ?axat-te. In some 
Levantine Arabic varieties, 'its price' is pronounced as Pimmit-tā. The definite article in OA has two forms, ( $(2) l$ - and (?a) $l$-. It is $l$ - in connected speech, unless the first syllable of the noun is open with an unstressed $/ \mathrm{i} / \mathrm{or} / \mathrm{u} /$, in which case the definite article is $l^{2}$-; for example, the definite form of kitāb is la-ktâb. This is also the case if the word is monosyllabic with the form $\mathrm{CC} \overline{\mathrm{V}} \mathrm{C}$, as in wläd 'children' whose definite form is $l \partial-w l \bar{a} d$, and byūt 'houses', whose definite form is la-byūt.

In addition, obstruents assimilate in voicing when in a cluster of two obstruents, resulting in two voiced or voiceless obstruents. For example, Piǰtima $\bar{a}$ ' 'meeting' becomes Pičtimā $\varsigma$ (or Pištimā̧), masgid 'mosque' becomes mazgid, tzawwag 'he got married' becomes dzawwag, and mugtahid 'hardworking' becomes muktahid in some BSD varieties. Moreover, when two obstruents identical except for voicing are adjacent accross word boundaries, the first assimilates to the second in voicing, resulting in a geminate, as in malt

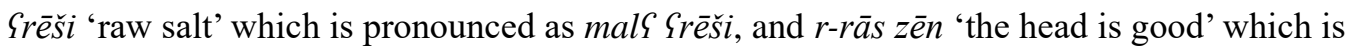
pronounced as $r-r \bar{a} z z \bar{e} n$. Furthermore, the labials $/ \mathrm{m} /$, /f/, and $/ \mathrm{b} /$ turn a following $/ \mathrm{n} /$ into $/ \mathrm{m} /$, as in ganb 'side', which becomes gamb, yinfax 'blow', which becomes yimfax, and min bètuh 'from his house', which becomes mim bètuh. Also, /n/ assimilates to /r/ when followed by $/ \mathrm{r} /$, as in man rasab 'who failed?' which becomes mar rasab.

Besides assimilation, OA dialects also exhibit the spread of emphasis, or velarization in the vicinity of emphatics. For example, /s/ is pronounced as /ș/ when around /ț/ as in șaț 'roof' (sațh) and șalațah 'salad' (salațah), as well as in the proper name șulțān (Sulțān); these examples also show that /l/ has an emphatic allophone, /l/, which appears in many of the Bedouin dialects in the vicinity of emphatics as well as uvulars, as in yz-štzyəl 'he works' (ya-štayil-u), mašxal 'sieve', and maq!āhh 'frying pan' (miqlāh). Also, /t/ is pronounced as /ț/ when around /ș/ as in țabbar 'have patience!' as well as in the tribal name Paș-șaḷti (it is Paș-ṣalti, after Imam Paṣ-ṣalt bin Mālik Al-Xarūṣi); in Egyptian Arabic,

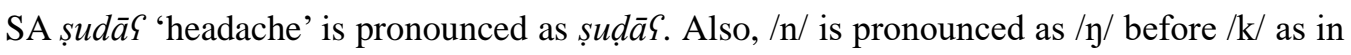
Pinkasar 'it broke' and yinkabb 'it pours', as well as before $/ \mathrm{g} /$, as in yingrah 'he gets injured' and yingāb 'it is brought'. Moreover, Glover notes that $/ \mathrm{r} /$ also has an emphatic allophone that appears in the vicinity of emphatic consonants, as in marat 'he pulled out' ( $\mathrm{p}$. 38).

Examples of metathesis in DSD include Allah y-naSl-oh 'may God curse him' from Allah y-laSn-oh, mSalqah 'spoon' from mil $a q a h$, and $g z \bar{a} z$ ' 'glass' from $z g \bar{a} g$. BSD has golb 'light bulb' from globe, and karhaba 'electricity' from kahrabā?. In the Șūr dialect, there is mityawza 'married' from mitzawga, where /g/ is realized as /y/ in most Bedouin dialects, as 
in yib-na 'we brought' (gib-na) and daray 'stairs' (darag). The distinction between past tense and imperative verbs is exhibited through ablaut in some OA dialects. For example, the imperative of $x \bar{a} z$ 'went away' is $x \bar{u} z$; the imperative of $x a \partial$ 'took' is $x o \partial$; the imperative of $\check{s} \bar{a} f$ 'saw' is $\check{s} \bar{u} f$; and the imperative of $r \bar{a} \hbar$ ' $\mathrm{go}$ ' is $r \bar{u} \hbar$.

\subsection{Phonotactics}

Some OA dialects allow certain sound combinations that are not allowed in other dialects. For example, MD allows clusters of 3 consonants word-initially, as in strï 'rest!' and stlim 'receive!', and word-medially, as in yi-strith 'he rests' and ni-stlim 'we receive'. In contrast, some northern mountains varieties (sedentary) break the cluster, as in sitrit 'rest!' and $y$-sitrith 'he rests'. Also, BSD breaks the cluster, as in yz-starith and yə-stilim 'he receives'.

Shaaban (1977:82) observes that when the suffix starts with a consonant in MD, the first vowel in the stem is deleted, as in qtal-ti 'you.sf killed' from qatal+ti. By contrast, when the suffix starts with a vowel, the second vowel is deleted, as in qatl-it 'she killed' from $q a t a l+i t$. This is also true of DSD, where qtal 'he killed' becomes qatl-et 'she killed' and $q t a l-t i$ 'you.sf killed'. In BSD, however, while the vowel-initial suffix causes the stem to lose its second vowel, as in qatl-it 'she killed', the consonant-initial suffix does not cause the stem to lose the first vowel, as in qatal-ti 'you.sf killed'. This is also true of the Ja?lān variety (Bedouin) where gital 'he killed' becomes gitl-at 'she killed' and gital-ti 'you.sf killed'. In the Șūr variety (Bedouin), the vowel-initial suffix does not cause the stem to lose its second vowel, as in wașal-an 'we arrived' (from Holes, 2013). Another pattern is observed in the Al-Mudaybi variety (mixed) where whether the suffix is consonant-initial or vowel-initial does not affect the stem since qtal 'he killed' becomes qtal-it 'she killed' and qtal-ti 'you.sf killed'.

Unlike some modern Arabic dialects, the perfective form of stems with geminates, like

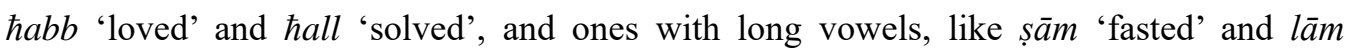
'blamed', does not always involve epenthesis when followed by a consonant-initial affix.

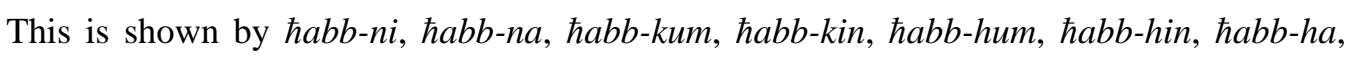
$\hbar a b b-o h, \hbar a b b-a k, \hbar a b b-i \check{s}$. For the $1^{\text {st }}$ person, while it is $\hbar a b b$-eni in Egyptian Arabic, it is $\hbar a b b$-ani in some Saudi varieties (Hijāz).

Finally, while MD doubles the consonant in the subject affix before the vowel-initial object suffix, as in katb-it-t-oh 'she wrote it', some BSD and northern mountains sedentary varieties have katbi-t-oh. Also, while DSD deletes unstressed short vowels in open non-final syllables, as in glast 'I sat down' and wqaft 'I stood up', BSD does not delete that 
vowel, the corresponding forms are galast and waqaft.

\section{Morphology}

This section presents several aspects of the morphology of OA. Forms are either sedentary or Bedouin, sometimes the name of the town in which the form is used is indicated. Sometimes the form is hard to identify with a specific town, but it certainly exists in an OA dialect since I have encountered it in the 15 year-long contact with speakers of several OA dialects. As is clear in some tables, some sedentary forms are identaical to the corresponding Bedouin ones, which reflects the fact that the dialects are converging.

\subsection{Personal pronouns}

The forms in table 5 are the masculine subject and object personal pronouns; the pronouns in table 6 are the feminine ones. Like all the modern dialects of Arabic, OA does not mark the dual in the pronominal system. The different forms come from different dialects; where known, the name of the city/town (in parentheses) follows the respective form, which could also be used in other parts of the country. It should be noted that while the subject pronouns are free morphemes, the object pronouns are suffixes.

Table 5. Masculine Personal Pronouns

\begin{tabular}{|c|c|c|c|c|c|c|}
\hline & $\begin{array}{l}1^{\text {st }} \text { Person } \\
\text { Singular }\end{array}$ & $\begin{array}{l}1^{\text {st }} \text { Person } \\
\text { Plural }\end{array}$ & $\begin{array}{l}2^{\text {nd }} \text { Person } \\
\text { Singular }\end{array}$ & $\begin{array}{l}2^{\text {nd }} \text { Person } \\
\text { Plural }\end{array}$ & $\begin{array}{l}3^{\text {rd }} \text { Person } \\
\text { Singular }\end{array}$ & $\begin{array}{l}3^{\text {rd }} \text { Person } \\
\text { Plural }\end{array}$ \\
\hline \multirow{2}{*}{$\begin{array}{l}\text { Subject } \\
\text { Pronouns }\end{array}$} & $\begin{array}{l}\text { Sedentary: } \\
\text { Pana } \\
\text { Pāni } \\
\text { (Șalālah) }\end{array}$ & 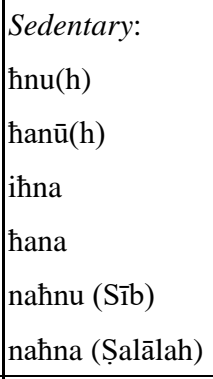 & $\begin{array}{l}\text { Sedentary: } \\
\text { Pintah } \\
\text { nta(h) } \\
\text { Pinta } \\
\text { (Șalālah) }\end{array}$ & $\begin{array}{l}\text { Sedentary: } \\
\text { Pintū(h) } \\
\text { ntū(h) } \\
\text { Pintu } \\
\text { (Ṣalālah) }\end{array}$ & $\begin{array}{l}\text { Sedentary: } \\
\text { huwwa } \\
\text { huwwo(h) } \\
\text { ho (Șalālah) }\end{array}$ & $\begin{array}{l}\text { Sedentary: } \\
\text { humma(h) } \\
\text { hum } \\
\text { hūm } \\
\text { (Șalālah) }\end{array}$ \\
\hline & $\begin{array}{l}\text { Bedouin: } \\
\text { Pani } \\
\text { Pana }\end{array}$ & $\begin{array}{l}\text { Bedouin: } \\
\text { han } \\
\text { hana } \\
\text { naћan } \\
\text { nəћən } \\
\text { hanna }\end{array}$ & $\begin{array}{l}\text { Bedouin: } \\
\text { Pint } \\
\text { Pintəh }\end{array}$ & $\begin{array}{l}\text { Bedouin: } \\
\text { (i)ntu } \\
\text { (i)ntaw }\end{array}$ & $\begin{array}{l}\text { Bedouin: } \\
\text { hū(h) } \\
\text { hu } \\
\text { huwwo(h) }\end{array}$ & $\begin{array}{l}\text { Bedouin: } \\
\text { hum } \\
\text { hummə(h) }\end{array}$ \\
\hline
\end{tabular}


Rashid Al-Balushi

\begin{tabular}{|c|c|c|c|c|c|c|}
\hline & $\begin{array}{l}\text { Sedentary: } \\
\text {-ni }\end{array}$ & $\begin{array}{l}\text { Sedentary: } \\
\text {-na }\end{array}$ & $\begin{array}{l}\text { Sedentary: } \\
\text {-ak }\end{array}$ & $\begin{array}{l}\text { Sedentary: } \\
\text {-kum } \\
\text {-čim }\end{array}$ & $\begin{array}{l}\text { Sedentary: } \\
\text {-oh } \\
\text {-uh }\end{array}$ & $\begin{array}{l}\text { Sedentary: } \\
\text {-hum } \\
\text {-him }\end{array}$ \\
\hline $\begin{array}{l}\text { Poject } \\
\text { Pronouns }\end{array}$ & $\begin{array}{l}\text { Bedouin: } \\
\text {-ni } \\
\text {-āni } \\
\text {-ānyəh }\end{array}$ & $\begin{array}{l}\text { Bedouin: } \\
\text {-na } \\
\text {-āna } \\
\text {-ānne }\end{array}$ & $\begin{array}{l}\text { Bedouin: } \\
\text {-ak } \\
\text {-āk }\end{array}$ & $\begin{array}{l}\text { Bedouin: } \\
\text {-kom } \\
\text {-ākum }\end{array}$ & $\begin{array}{l}\text { Bedouin: } \\
\text {-ah } \\
\text {-āh }\end{array}$ & $\begin{array}{l}\text { Bedouin: } \\
\text {-hom } \\
\text {-āhum }\end{array}$ \\
\hline
\end{tabular}

Table 6. Feminine Personal Pronouns

\begin{tabular}{|c|c|c|c|c|c|c|}
\hline & $\begin{array}{l}1^{\text {st }} \text { Person } \\
\text { Singular }\end{array}$ & $\begin{array}{l}1^{\text {st }} \text { Person } \\
\text { Plural }\end{array}$ & $\begin{array}{l}2^{\text {nd }} \text { Person } \\
\text { Singular }\end{array}$ & $\begin{array}{l}2^{\text {nd }} \text { Person } \\
\text { Plural }\end{array}$ & $\begin{array}{l}3^{\text {rd }} \text { Person } \\
\text { Singular }\end{array}$ & $\begin{array}{c}3^{\text {rd }} \text { Person } \\
\text { Plural }\end{array}$ \\
\hline \multirow{2}{*}{$\begin{array}{l}\text { Subject } \\
\text { Pronouns }\end{array}$} & $\begin{array}{l}\text { Sedentary: } \\
\text { Pana } \\
\text { Pāni } \\
\text { (Șalālah) }\end{array}$ & 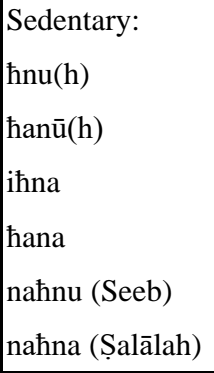 & $\begin{array}{l}\text { Sedentary: } \\
\text { ntī(h) } \\
\text { Pinti } \\
\text { (Șalālah) }\end{array}$ & $\begin{array}{l}\text { Sedentary: } \\
\text { Pintan } \\
\text { ntan } \\
\text { Pintin } \\
\text { (Șalālah) }\end{array}$ & $\begin{array}{l}\text { Sedentary: } \\
\text { hiyya(h) } \\
\text { hi } \\
\text { (Șalālah) }\end{array}$ & $\begin{array}{l}\text { Sedentary: } \\
\text { hinnah } \\
\text { hin } \\
\text { hēn } \\
\text { (Șalālah) }\end{array}$ \\
\hline & $\begin{array}{l}\text { Bedouin: } \\
\text { Pani } \\
\text { Pana }\end{array}$ & $\begin{array}{l}\text { Bedouin: } \\
\text { han } \\
\text { hana } \\
\text { nahan } \\
\text { nəћən } \\
\text { hanna }\end{array}$ & $\begin{array}{l}\text { Bedouin: } \\
\text { nti } \\
\text { (i)ntay }\end{array}$ & $\begin{array}{l}\text { Bedouin: } \\
\text { ntin } \\
\text { ntan }\end{array}$ & $\begin{array}{l}\text { Bedouin: } \\
\text { hiyya(h) } \\
\text { hi } \\
\text { hī(h) } \\
\text { hiyyə(h) }\end{array}$ & $\begin{array}{l}\text { Bedouin: } \\
\text { hēn } \\
\text { hin } \\
\text { hinnəh }\end{array}$ \\
\hline \multirow[b]{2}{*}{$\begin{array}{l}\text { Object } \\
\text { Pronouns }\end{array}$} & $\begin{array}{l}\text { Sedentary: } \\
\text {-ni } \\
\text {-āni }\end{array}$ & $\begin{array}{l}\text { Sedentary: } \\
\text {-na } \\
\text {-āna }\end{array}$ & $\begin{array}{l}\text { Sedentary: } \\
\text {-ǐ̌s } \\
\text {-āš }\end{array}$ & $\begin{array}{l}\text { Sedentary: } \\
\text {-kin } \\
\text {-ākin } \\
\text {-čin }\end{array}$ & $\begin{array}{l}\text { Sedentary: } \\
\text {-ha } \\
\text {-āha }\end{array}$ & $\begin{array}{l}\text { Sedentary: } \\
\text {-hin } \\
\text {-āhin }\end{array}$ \\
\hline & $\begin{array}{l}\text { Bedouin: } \\
\text {-ni } \\
\text {-ānyəh } \\
\text { (Suwaiq) }\end{array}$ & $\begin{array}{l}\text { Bedouin: } \\
\text {-na } \\
\text {-ānne } \\
\text { (Suwaiq) }\end{array}$ & $\begin{array}{l}\text { Bedouin: } \\
\text {-ič } \\
\text {-iš } \\
\text {-ik } \\
\text {-âk } \\
\text { (Suwaiq) }\end{array}$ & $\begin{array}{l}\text { Bedouin: } \\
\text {-kan } \\
\text {-kin } \\
\text {-ākin } \\
\text { (Suwaiq) }\end{array}$ & $\begin{array}{l}\text { Bedouin: } \\
\text {-he } \\
\text {-hi } \\
\text { (Suwaiq) }\end{array}$ & $\begin{array}{l}\text { Bedouin: } \\
\text {-hin } \\
\text {-āhin } \\
\text { (Suwaiq) }\end{array}$ \\
\hline
\end{tabular}




\section{Omani Arabic: More than a Dialect}

\subsection{Demonstrative pronouns}

The different OA varieties have different forms for the demonstrative pronoun which corresponds to the SA hă $\bar{a} \bar{a}$ 'this' and its forms for masculine and feminine as well as singular and plural, as in table 7. Demonstrative pronouns in OA may also follow the noun, as in $m \bar{a}$ šaf-t-oh r-riggāl hă $\bar{a} \bar{a}$ 'I have not seen this man'.

Table 7. OA Demonstrative Pronouns

\begin{tabular}{|c|c|c|c|c|}
\hline & $\begin{array}{l}\text { Proximal Masculine } \\
\text { Singular }\end{array}$ & $\begin{array}{l}\text { Proximal Masculine } \\
\text { Plural }\end{array}$ & $\begin{array}{l}\text { Distal Masculine } \\
\text { Singular }\end{array}$ & $\begin{array}{l}\text { Distal Masculine } \\
\text { Plural }\end{array}$ \\
\hline \multirow[t]{2}{*}{ Masculine } & $\begin{array}{l}\text { Sedentary: } \\
\text { hāða } \\
\text { hāði (Șalālah) } \\
\text { ha } \\
\text { ða } \\
\text { ðohoh } \\
\text { (northern mountains) }\end{array}$ & $\begin{array}{l}\text { Sedentary: } \\
\text { haðēla/hāðēle } \\
\text { ðēla/ð̄ēle } \\
\text { ha } \\
\text { haðōna (Șalālah) } \\
\text { ðēlhoh } \\
\text { (northern mountains) }\end{array}$ & $\begin{array}{l}\text { Sedentary: } \\
\text { hāðāk } \\
\text { ðāk } \\
\text { Paðāk(ah) } \\
\text { haðāk(ah) } \\
\text { hāk (Ṣalālah) } \\
\text { haðāk-əh } \\
\text { (Al-Hamra) }\end{array}$ & $\begin{array}{l}\text { Sedentary: } \\
\text { hāðēlāk } \\
\text { hāōōna } \\
\text { hāðalāk } \\
\text { (Al-Hamra) } \\
\text { hiyy-hum } \\
\text { (Al-Hamra) } \\
\text { dēlāk } \\
\text { haðōnak } \\
\text { (Șalālah) }\end{array}$ \\
\hline & $\begin{array}{l}\text { Bedouin: } \\
\text { ðē(h) } \\
\text { ha } \\
\text { hað̄̄ (Bidiyya) } \\
\text { Paðēe (Șūr) } \\
\text { hāðiya (Șūr) } \\
\text { Pē (Șūr) } \\
\text { hāðēh (Suwaiq) }\end{array}$ & $\begin{array}{l}\text { Bedouin: } \\
\text { Pāllā(h) Șūr } \\
\text { ha } \\
\text { hāoēla (Suwaiq) } \\
\text { ðēla }\end{array}$ & $\begin{array}{l}\text { Bedouin: } \\
\text { hāðāk } \\
\text { ðāk } \\
\text { (Suwaiq) }\end{array}$ & $\begin{array}{l}\text { Bedouin: } \\
\text { Pāllāk } \\
\text { hāoēlāk } \\
\text { ðēelāk } \\
\text { (Suwaiq) }\end{array}$ \\
\hline Feminine & $\begin{array}{l}\text { Sedentary: } \\
\text { hāoi (Șalālah) } \\
\text { ha } \\
\text { ði } \\
\text { ðihoh }\end{array}$ & $\begin{array}{l}\text { Sedentary: } \\
\text { haðēla/hāðēle } \\
\text { ðēla/ðēle } \\
\text { ðēlhoh } \\
\text { (northern mountains) } \\
\text { haðēna (DSD) }\end{array}$ & 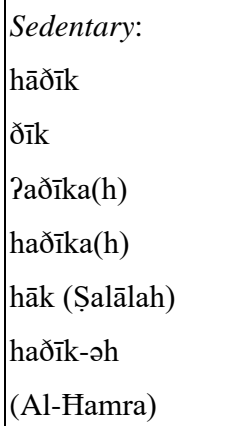 & $\begin{array}{l}\text { Sedentary: } \\
\text { hāðēlāk } \\
\text { hāðōna } \\
\text { ðēlāk } \\
\text { haðēnak } \\
\text { (Ṣalālah) } \\
\text { hiyy-hin } \\
\text { (Al-Hamra) }\end{array}$ \\
\hline
\end{tabular}




\section{Rashid Al-Balushi}

\begin{tabular}{|c|c|c|c|}
\hline $\begin{array}{l}\text { Bedouin: } \\
\text { ha } \\
\text { Pað̄ina(h) } \\
\text { hað̄îha(h) } \\
\text { P̄ì (Al-Muḍaybi) } \\
\text { hāði } \\
\text { ð̄̄ } \\
\text { (Suwaiq) }\end{array}$ & $\begin{array}{l}\text { Bedouin: } \\
\text { Pāllā(h) Șūr } \\
\text { ha } \\
\text { ðēla } \\
\text { hāđēla } \\
\text { (Suwaiq) }\end{array}$ & $\begin{array}{l}\text { Bedouin: } \\
\text { hāđōik } \\
\text { ð̄̄k } \\
\text { (Suwaiq) }\end{array}$ & $\begin{array}{l}\text { Bedouin: } \\
\text { Pāllāk } \\
\text { dēlāk } \\
\text { (Suwaiq) }\end{array}$ \\
\hline
\end{tabular}

\subsection{Possessive pronouns}

As in SA, possession in OA is expressed by possessive pronouns suffixed to the noun, as table 8 shows.

Table 8. OA Possessive Pronouns

\begin{tabular}{|c|c|c|c|c|c|c|}
\hline & $\begin{array}{l}1^{\text {st }} \text { Person } \\
\text { Singular }\end{array}$ & $\begin{array}{c}1^{\text {st }} \text { Person } \\
\text { Plural }\end{array}$ & $\begin{array}{c}2^{\text {nd }} \text { Person } \\
\text { Singular }\end{array}$ & $\begin{array}{c}2^{\text {nd }} \text { Person } \\
\text { Plural }\end{array}$ & $\begin{array}{c}3^{\text {rd }} \text { Person } \\
\text { Singular }\end{array}$ & $\begin{array}{c}3^{\text {rd }} \text { Person } \\
\text { Plural }\end{array}$ \\
\hline \multirow[t]{2}{*}{ Masculine } & $\begin{array}{l}\text { Sedentary: } \\
-\mathrm{i}\end{array}$ & $\begin{array}{l}\text { Sedentary: } \\
\text {-na }\end{array}$ & $\begin{array}{l}\text { Sedentary: } \\
\text {-ak } \\
-\mathrm{ač}\end{array}$ & $\begin{array}{l}\text { Sedentary: } \\
\text {-kum }\end{array}$ & $\begin{array}{l}\text { Sedentary: } \\
\text {-oh } \\
\text {-eh } \\
\text {-uh }\end{array}$ & $\begin{array}{l}\text { Sedentary: } \\
\text {-hum }\end{array}$ \\
\hline & $\begin{array}{l}\text { Bedouin: } \\
\text {-iyəh } \\
\text { (Suwaiq) }\end{array}$ & $\begin{array}{l}\text { Bedouin: } \\
\text {-ni }\end{array}$ & $\begin{array}{l}\text { Bedouin: } \\
\text {-ək }\end{array}$ & $\begin{array}{l}\text { Bedouin: } \\
\text {-kum }\end{array}$ & $\begin{array}{l}\text { Bedouin: } \\
\text {-ah } \\
\text {-əh }\end{array}$ & $\begin{array}{l}\text { Bedouin: } \\
\text {-hum }\end{array}$ \\
\hline \multirow{2}{*}{ Feminine } & $\begin{array}{l}\text { Sedentary: } \\
-\mathrm{i}\end{array}$ & $\begin{array}{l}\text { Sedentary: } \\
\text {-na }\end{array}$ & $\begin{array}{l}\text { Sedentary: } \\
\text {-ǐ̌ }\end{array}$ & $\begin{array}{l}\text { Sedentary: } \\
\text {-kin } \\
\text {-kan }\end{array}$ & $\begin{array}{l}\text { Sedentary: } \\
\text {-ha } \\
\text {-he }\end{array}$ & $\begin{array}{l}\text { Sedentary: } \\
\text {-hin }\end{array}$ \\
\hline & $\begin{array}{l}\text { Bedouin: } \\
\text {-iyəh } \\
\text { (Suwaiq) }\end{array}$ & $\begin{array}{l}\text { Bedouin: } \\
\text {-ni }\end{array}$ & $\begin{array}{l}\text { Bedouin: } \\
\text {-ič (Al-Buraimi) } \\
\text {-ik (Āl-Wahība) }\end{array}$ & $\begin{array}{l}\text { Bedouin: } \\
\text {-kin }\end{array}$ & $\begin{array}{l}\text { Bedouin: } \\
\text {-ha } \\
\text {-hi }\end{array}$ & $\begin{array}{l}\text { Bedouin: } \\
\text {-hin }\end{array}$ \\
\hline
\end{tabular}

It is noteworthy that the $1^{\text {st }}$ person singular possessive pronoun of the Bedouin dialect of the town of Suwaiq on the Bātina coast is reminiscent of that used on words in the QurPānic verses 19-20:69 and 25-26:69, "kitāb-iyah" 'my book' and "hisāb-iyah" 'my account', as well as in the verses 28-29:69, in (5-6). This 'yah' is called hā?u-s-sakt in Sībawayhi's Kitāb ( $8^{\text {th }}$ century).

$\begin{array}{clcl}\text { (5) mā } & \text { Paynā } & \text { Yannī } & \text { māl-iyah } \\ \text { Neg } & \text { Pst.benefit.3sm } & \text { from.me } & \text { money-my }\end{array}$




\section{Omani Arabic: More than a Dialect}

'My wealth has not availed me.'

(6) halaka Sulțān-iyah Sanni (29:69)

Pst.perish.3sm from.me authority-my

'My authority has abandoned me.'

It is also worth mentioning that $-a k$ and $-i \check{s}$ (singular possive pronouns), as used in some Bedouin varieties, have two forms. For example, while 'your.sm book' is $k t a \bar{b}-a k$, 'your.sm car' is sayyārat-k. Similarly, while 'your.sf book' is $k t \bar{a} b-i \check{s}$, 'your.sf car' is sayyārat-š. It seems that when the last vowel in the noun stem is long, the longer (vowel-initial) form of the pronoun is used. This is supported by the fact that 'your.sm cars' in these Bedouin varieties is sayyārāt-ak and 'your.sf cars' is sayyārāt-iš; sayyārāt-k and sayyārāt-š are illicit.

That this is on the right track is supported by words like markab 'boat', 'your.sm boat' is

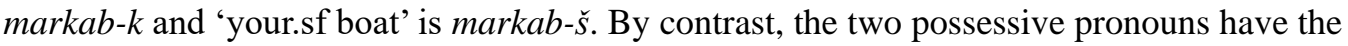
same form in the sedentary dialelcts, as in ktāb-ak, markab-ak, siyyārt-ak, and siyyārāt-ak; this also applies to $-i \check{s}$.

Ownership is expressed in OA by the free morpheme $m \bar{a} l$, which takes the possessive pronoun as a suffix, thus (?i)l-ktāb māl-i means 'my book' or 'the book of mine', $\hbar \bar{a} l$ has the same meaning of $m \bar{a} l$, but it is used differently, we say (Pi)l-ktāb $b \bar{u} \hbar \bar{a} l-i$ 'the book of mine/the book which belongs to me'. (?i)l-ktāb $\hbar \bar{a} l-i$ means 'the/this book is mine', a full sentence.

The southern dialects have the free morpheme $\hbar a q q$ (also found in some of the Yemeni dialects), thus 'the book of mine/my book' is (?i)l-ktāb $\hbar a q q-i$. While $m \bar{a} l$ in the northern dialects realizes plural number and feminine gender optionally, as in māl-t-i (?is-siyyārah $m \bar{a} l-i / m \bar{a} l-t-i$ 'my car') and $m \bar{a} l-\bar{a}-t-i$ (?is-siyyārāât $m \bar{a} l-i / m \bar{a} l-\bar{a}-t-i$ 'my cars'), it must realize both number and gender of the possessee in DSD, thus there is $m \bar{a} l-i, m \bar{a} l-t-i$, and $m \bar{a} l-\bar{u}-t-i$, as in (?i)l-?awrāq $m \bar{a} l-\bar{u}-t-i$ 'my papers'. Likewise, $\hbar a q q$ must realize gender and number of the possessee, thus 'the car of mine' is ?is-siyyārah $\hbar a q q-\partial t-i$, and 'the cars of mine' is Pis-siyyārāt $\hbar a q q-\bar{u}-t-i$. It is possible that māli comes from SA, analyzed as $m \bar{a}-l-i$, where $m \bar{a}$ is a relative pronoun meaning 'what', $-l$ - is the preposition meaning 'for/of', and $-i$ is the $1^{\text {st }}$ person singular possessive pronoun, together amounting to 'what is for me/what belongs to me', māll-i and $\hbar a q q-i$ correspond to SA xāṣsatī.

\subsection{Interrogative pronouns}

This section presents the different interrogative pronouns in the various OA dialects, in table 9. Some of the interrogative pronouns corresponding to 'what' are composed of ?a- 
(whose glottal stop has transformed into either $w$ - or $y$ - or $h$ - in different varieties), which may be the first syllable of the SA $? a-y y u$ 'which', and $-\check{s}$, which may arguably be a grammaticalization of the OA noun šay 'thing' (šay? in SA). Thus 'what' is basically 'which thing'. Likewise, some of the pronouns corresponding to 'why' are composed of the same structure of 'what' plus the prefixal preposition $l$-, meaning 'for', or the possessive $\hbar \bar{a} l$, which means 'for' (as in $l-k t \bar{a} b$ bu $\hbar \bar{a} l i$ 'my book/the book which is for me'), amounting to 'what for'. Other patterns are observed in the other pronoun forms.

Table 9. OA Interrogative Pronouns

\begin{tabular}{|c|c|}
\hline Wh-word & OA Equivalents \\
\hline What & Pēš; wēš; hēš; šū; mūu(h); yīš; mhu; kūn (Suwaiq) \\
\hline Who & min; mən; man; min-hu; min-u \\
\hline Where & wēn; hēn \\
\hline When & mata; məta; mita; miti (Suwaiq) \\
\hline Why & 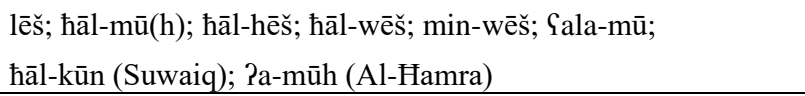 \\
\hline How & kēf; kama-mū (like what) \\
\hline How many & kam; kam-min; š-gadd (what amount/size) \\
\hline Whose & ћāl-min; māl-min; b-ћāl-min (Al-Hamra) \\
\hline Which of & $\begin{array}{l}\text { hēn-min(-hum/-hin); wēn-min(-hum/-hin); mū-min(-hum/-hin); } \\
\text { hēš-min(-hin); kūn-min(-hin) (Suwaiq) }\end{array}$ \\
\hline
\end{tabular}

\subsection{Plural marking in OA nouns}

Many of the nouns in OA have both a sound plural form and a broken one. For example, the sound plural form of siyyārah 'car' is siyyārāt (sound plural feminine), but it also has the form sayāyìr (broken); the sound plural form of $s \bar{a} \varphi a h$ 'watch' is $s \bar{a} \varphi \bar{a} t$, but there is also

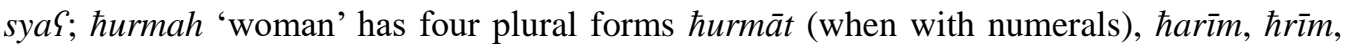

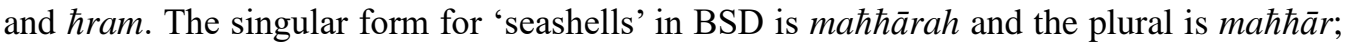

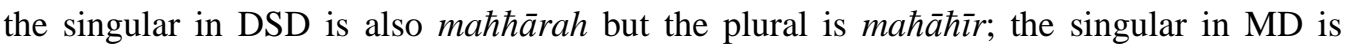

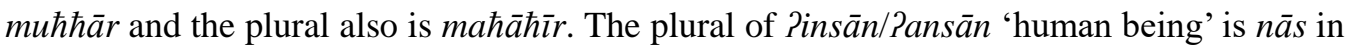
all the OA dialects, but DSD also has $n \bar{\imath} s$. DSD and MD are probably the most peculiar with regard to their pluralization patterns, a topic which lends itself to thorough examination and analysis; table 10 presents some of the most notable examples.

Table 10. Notable Pluralization Patterns

\begin{tabular}{||l|l|l|l|l|l||}
\hline \hline & Singular and Meaning & DSD & MD & Bāṭina & Other Dialects \\
\hline 1 & Pustāð ‘teacher’ & Pustāð-īn, Pasātīð & Pasātīð & Pasātðah, Pasātīo & Pasātīd, Pustādīn \\
\hline 2 & šurți 'policeman’ & šurṭiyy-īn, šurțah & šurțah, šurțiyy-īn & šurțah & šarțah \\
\hline
\end{tabular}


Omani Arabic: More than a Dialect

\begin{tabular}{|c|c|c|c|c|c|}
\hline 3 & $\begin{array}{l}\text { bāb 'door' } \\
\text { DSD: bāb; bīb }\end{array}$ & bībān, bwīb & bībān & bībān & (Pa)bwāb \\
\hline 4 & Zgāg 'glass' & zgīg (pieces) & zgāg & zgāg & zgāg \\
\hline 5 & $\begin{array}{l}\text { dgāgah 'chicken' } \\
\text { DSD: dgāgah; dgōgah } \\
\text { Bedouin: dyāyah }\end{array}$ & dəgīg, dgōg & dgāg & dgāg, dyāy & dyāy, diyāy \\
\hline 6 & gdār 'wall' & gidwār & gidrān & gidrān & gidər \\
\hline 7 & $\begin{array}{l}\text { hașāh; hṣāh 'stone' } \\
\text { DSD: həgārah }\end{array}$ & ћəgwār & həșyāt, ћușyāt & hașa & hși \\
\hline 8 & nYāl 'shoes' & naYālāt & nuYlān & niSil & niৎlān, nYūl \\
\hline 9 & mațbax 'kitchen' & mṭābax & mațābax, mațābox & mațābəx & mațābox \\
\hline 10 & Өallāgah 'fridge' & Oallāgāt & $\theta$ alālīg & Oallāgāt & \\
\hline 11 & kōb 'cup' & kōbāt, kwīb, kūbīt & kībān & kōbāt & (Pa)kwāb \\
\hline 12 & $\begin{array}{l}\text { hașīr 'mat' } \\
\text { DSD: hașīr; simmah }\end{array}$ & həșrān, smām & hașāyar & ћəșrān & həșər \\
\hline 13 & gabal 'mountain' & gbal, gbāl & gbāl & gbāl & \\
\hline 14 & gamal 'camel' & gmal, gmāl, Pibil & gmāl & gmāl, bōš & $\begin{array}{l}\text { hīn (SA hiǰin, } \\
\text { higin in } \mathrm{OA} \text { ) }\end{array}$ \\
\hline 15 & $\begin{array}{l}\text { zlāy ‘sock’ } \\
\text { DSD: dəlāy } \\
\text { MD: dlāy }\end{array}$ & dalāyāt & dilyān & zlāyāt & \\
\hline 16 & ktāb 'book' & kutbāt, kutub & ktub & kutub, kitib & \\
\hline 17 & qalam 'pen' & qalmāt & qlāmah & Paqlām, qlāmah & \\
\hline 18 & $\begin{array}{l}\text { Yors; Girs 'wedding' } \\
\text { DSD: Yoros }\end{array}$ & Garsāt & Grūsāt & Grūsāt & Pałrās \\
\hline 19 & nāqah 'female camel' & nāq & & & nūg, nāqāt \\
\hline 20 & $\begin{array}{l}\text { riggāl 'man' } \\
\text { DSD: riggīl; riggāl }\end{array}$ & rgīl & rgāl & rgāl, rgāgīl & ragāgīl, riyāyīl \\
\hline
\end{tabular}

\subsection{Verb forms and structure}

Unlike SA, which has 15 trilateral verb forms and 4 quadrilateral forms, OA has 9 trilateral forms (lacking 4 and 11-15) and 2 quadrilateral ones (lacking 3 and 4). Shaaban (1977:51-52) states that MD lacks Form IX, and that Form IV verbs are rare, except for borrowings from SA. Though rare, Form IX is available in BSD, which lacks Form IV. 
Form IX is sometimes replaced with participles, and Form IV by Form I verbs, unless borrowed from SA. Table 11 provides the forms with examples.

Table 11. OA 11 Verb Forms

\begin{tabular}{|c|c|c|}
\hline Forms & SA Metrics & OA Examples \\
\hline Tri-Form I & faSala & katab 'write'; la؟ab 'play' \\
\hline Tri-Form II & faৎ̧ala & kallam 'talk to'; rawwah 'leave' \\
\hline Tri-Form III & fā̧ala & šārak 'participate'; sāmah 'forgive' \\
\hline Tri-Form V & tafaŞala & tšawwaf 'see'; twassạ ‘widen' \\
\hline Tri-Form VI & tafā̧ala & thāwan 'recover'; ţāwan 'cooperate' \\
\hline Tri-Form VII & PinfaSala & Pinqalab 'flip'; Pinsaћab ‘withdraw' \\
\hline Tri-Form VIII & PiftaSala & Pigtahad 'work hard'; Pimtaћan 'take a test' \\
\hline Tri-Form IX & Pifৎalla & Piftarr 'skid/slide'; Pișțamm 'become deaf' \\
\hline Tri-Form X & PistafYala & Pistaxdam 'use'; PistaSbat 'ignore' \\
\hline Quadri-Form I & faslala & zaxraf 'decorate'; sayțar 'control' \\
\hline Quadri-Form II & tafaSlala & tPaqlam 'get used to'; txarbaṭ 'mess up' \\
\hline
\end{tabular}

Shaaban (1977:126) states that the basic perfective stem in MD is always $\mathrm{CaCaC}$, thus the perfective form for kataba 'write' in MD is katab. By contrast, it is kitab in some Bățina Bedouin varieties, ktab in DSD, and both kitab and ktab are found in different eastern varieties. The basic imperfective stem takes the form CCVC. For a tri-consonantal verb (sound), like katab, the imperfective is either yi-ktib, as in most OA dialects, or yi-ktob, as in DSD and some northern mountains varieties. Shaaban (1977:141-142) states that the MD imperfective form of glide-initial verbs (assimilated) like wașal 'arrive' and yabas 'dry up' is $y \bar{u}$-șal and $y \bar{l}$-bas, respectively, where the glide turns into a long vowel. DSD and BSD, however, allow the glide to surface, as in yu-wșallyz-wșal and yz-ybas. As for bi-consonantal verbs with a glide/long vowel in between (hollow), like țāl 'lengthen', while the imperfective in MD is $y-t \underline{u} l$, it is $y \partial-t w a l$ in other dialects. As for verbs with the form $\mathrm{CaCa}$ and a glide as the third radical when inflected in SA (defective), like nasa 'forget', the imperfective in MD is $y i-n s-u$ 'they forget', whereas it is $y$-nisy- $u$ in other dialects, like the one spoken in Sỉb in the Capital area. While the BSD imperfective form of $g a$ 'come' is $y-g-u$ 'they come' and of tyadda 'take lunch' is yi-tyadd-u 'they are taking lunch', the MD variety spoken in Sīb city has y-giyy-u and yi-t-yaddy-u, and one northern mountains dialect (sedentary) has $y i-t-y a d d a y-u$, allowing the glide to surface; Holes $(2007,2014$ ) states that the preservation of $/ y /$, a feature not available in many other Omani and Arabic dialects, is only found in OA sedentary dialects. The fact that some dialects allow a glide to 
surface in assimilated, hollow and defective verbs argues against Shaaban (1977:125) who states that the superficially bi-consonantal forms are actually formed of two consonants, without a glide in their underlying representation "since there is no independent motivation synchronically for positing underlying glides". (1)

\subsection{Subject agreement affixes}

This section presents the subject agreement affixes in perfective, imperfective, and active participle paradigms for both genders, in tables 12, and 13, respectively. Since different dialects have slightly different verbal forms, and also different affixes, the subject affixes are presented affixed to the verb katab 'write'. See Shaaban (1977:125-207) for the suffixes of all the verbal form patterns in MD. Some forms appear in both dialect groups, sedentary and Bedouin, reflecting dialect convergence and mixing.

Table 12. Masculine Subject Agreement Affixes

\begin{tabular}{|c|c|c|c|c|c|c|}
\hline & $\begin{array}{l}1^{\text {st }} \text { Person } \\
\text { Singular }\end{array}$ & $\begin{array}{l}1^{\text {st }} \text { Person } \\
\text { Plural }\end{array}$ & $\begin{array}{c}2^{\text {nd }} \text { Person } \\
\text { Singular }\end{array}$ & $\begin{array}{c}2^{\text {nd }} \text { Person } \\
\text { Plural }\end{array}$ & $\begin{array}{c}3^{\text {rd }} \text { Person } \\
\text { Singular }\end{array}$ & $\begin{array}{c}3^{\text {rd }} \text { Person } \\
\text { Plural }\end{array}$ \\
\hline \multirow{2}{*}{$\begin{array}{l}\text { Subject } \\
\text { Affixes in the } \\
\text { Imperfective }\end{array}$} & $\begin{array}{l}\text { Sedentary: } \\
\text { Pa-ktib } \\
\text { Pa-ktob } \\
\text { (Ṣalālah) }\end{array}$ & $\begin{array}{l}\text { Sedentary: } \\
\text { ni-ktib } \\
\text { nə-ktob } \\
\text { (Șalālah) }\end{array}$ & $\begin{array}{l}\text { Sedentary: } \\
\text { ti-ktib } \\
\text { tə-ktob } \\
\text { (Șalālah) }\end{array}$ & $\begin{array}{l}\text { Sedentary: } \\
\text { t-kitb-u } \\
\text { t-kitb-ūn } \\
\text { (Șalālah) }\end{array}$ & $\begin{array}{l}\text { Sedentary: } \\
\text { yi-ktib } \\
\text { yi-ktob } \\
\text { (Șalālah) }\end{array}$ & $\begin{array}{l}\text { Sedentary: } \\
\text { y-kitb-u } \\
\text { yi-kitb-u } \\
\text { y-kitb-ūn } \\
\text { (Șalālah) }\end{array}$ \\
\hline & $\begin{array}{l}\text { Bedouin: } \\
\text { Pa-ktib }\end{array}$ & $\begin{array}{l}\text { Bedouin: } \\
\text { na-ktib } \\
\text { ni-ktib }\end{array}$ & $\begin{array}{l}\text { Bedouin: } \\
\text { ta-ktib } \\
\text { ti-ktib }\end{array}$ & $\begin{array}{l}\text { Bedouin: } \\
\text { t-kitb-ūn } \\
\text { t-katb-ūn } \\
\text { t-katb-u }\end{array}$ & $\begin{array}{l}\text { Bedouin: } \\
\text { ya-ktib } \\
\text { yi-ktib }\end{array}$ & $\begin{array}{l}\text { Bedouin: } \\
\text { y-kitb-ōn } \\
\text { y-katb-u } \\
\text { y-katb-ūn } \\
\text { y-kitb-ūn }\end{array}$ \\
\hline $\begin{array}{l}\text { Subject } \\
\text { Affixes in the } \\
\text { Perfective }\end{array}$ & $\begin{array}{l}\text { Sedentary: } \\
\text { katab-t } \\
\text { ktab-t } \\
\text { ktib-t } \\
\text { (Șalālah) }\end{array}$ & $\begin{array}{l}\text { Sedentary: } \\
\text { katab-na } \\
\text { ktab-na } \\
\text { ktib-na } \\
\text { (Șalālah) }\end{array}$ & $\begin{array}{l}\text { Sedentary: } \\
\text { katab-t } \\
\text { ktab-t } \\
\text { ktib-t } \\
\text { (Șalālah) }\end{array}$ & $\begin{array}{l}\text { Sedentary: } \\
\text { katab-tu } \\
\text { ktab-tu } \\
\text { kətb-u } \\
\text { (Salālah) }\end{array}$ & $\begin{array}{l}\text { Sedentary: } \\
\text { katab } \\
\text { ktab } \\
\text { ktəb } \\
\text { (Salālah) }\end{array}$ & $\begin{array}{l}\text { Sedentary: } \\
\text { katb-u } \\
\text { ktab-u } \\
\text { kətb-u } \\
\text { (Salālah) }\end{array}$ \\
\hline
\end{tabular}

(1) See Shaaban (1977:54) and Glover (1988:165) for the perfective and imperfective verb forms and affixes in MD. As for most of the other dialects, the verbal forms and affixes will differ mainly in whether consonant clusters, gemination, vowel lengthening, or epenthesis is involved. 
Rashid Al-Balushi

\begin{tabular}{|l|l|l|l|l|l|l||}
\hline & Bedouin: & Bedouin: & Bedouin: & Bedouin: & Bedouin: & Bedouin: \\
kitab-t & kitab-na & kitab-t & ktab-taw & ktab & ktab-u \\
ktab-t & ktab-na & kitab-it & ktab-tu & kitab & ktab-aw \\
kitab-it & kitab-ni & (Suwaiq) & kitab-tu & & ktib-u \\
& (Suwaiq) & & kitab-taw & & (i)ktib-aw \\
& & & & & katb-aw \\
(Suwaiq)
\end{tabular}

Table 13. Feminine Subject Agreement Affixes

\begin{tabular}{|c|c|c|c|c|c|c|}
\hline & $\begin{array}{l}1^{\text {st }} \text { Person } \\
\text { Singular }\end{array}$ & $\begin{array}{c}1^{\text {st }} \text { Person } \\
\text { Plural }\end{array}$ & $\begin{array}{l}2^{\text {nd }} \text { Person } \\
\text { Singular }\end{array}$ & $\begin{array}{l}2^{\text {nd }} \text { Person } \\
\text { Plural }\end{array}$ & $\begin{array}{l}3^{\text {rd }} \text { Person } \\
\text { Singular }\end{array}$ & $\begin{array}{c}3^{\text {rd }} \text { Person } \\
\text { Plural }\end{array}$ \\
\hline \multirow[b]{2}{*}{$\begin{array}{l}\text { Subject } \\
\text { Affixes in the } \\
\text { Imperfective }\end{array}$} & $\begin{array}{l}\text { Sedentary: } \\
\text { Pa-ktib } \\
\text { Pa-ktob } \\
\text { (Șalālah) }\end{array}$ & $\begin{array}{l}\text { Sedentary: } \\
\text { ni-ktib } \\
\text { nə-ktob } \\
\text { (Șalālah) }\end{array}$ & $\begin{array}{l}\text { Sedentary: } \\
\text { t-kitb-i } \\
\text { t-kutb-īn } \\
\text { (Șalālah) }\end{array}$ & $\begin{array}{l}\text { Sedentary: } \\
\text { t-kitb-in } \\
\text { t-kitb-an } \\
\text { t-kutb-en } \\
\text { (Șalālah) }\end{array}$ & $\begin{array}{l}\text { Sedentary: } \\
\text { ti-ktib } \\
\text { tə-ktob } \\
\text { (Șalālah) }\end{array}$ & $\begin{array}{l}\text { Sedentary: } \\
\text { y-kitb-in } \\
\text { y-kitb-an } \\
\text { yə-kutb-en } \\
\text { (Șalālah) }\end{array}$ \\
\hline & $\begin{array}{l}\text { Bedouin: } \\
\text { Pa-ktib }\end{array}$ & $\begin{array}{l}\text { Bedouin: } \\
\text { na-ktib } \\
\text { n-katib } \\
\text { ni-ktib } \\
\text { (Suwaiq) }\end{array}$ & $\begin{array}{l}\text { Bedouin: } \\
\text { t-kitb-ay } \\
\text { (Ṣūr) } \\
\text { t-katb-i } \\
\text { t-katb-īn } \\
\text { t-kitb-īn } \\
\text { (Suwaiq) }\end{array}$ & $\begin{array}{l}\text { Bedouin: } \\
\text { t-katb-an } \\
\text { t-kitb-an } \\
\text { (Suwaiq) }\end{array}$ & $\begin{array}{l}\text { Bedouin: } \\
\text { ta-ktib } \\
\text { t-katib } \\
\text { ti-ktib } \\
\text { (Suwaiq) }\end{array}$ & $\begin{array}{l}\text { Bedouin: } \\
\text { y-katb-an } \\
\text { y-kitb-an } \\
\text { (Suwaiq) }\end{array}$ \\
\hline $\begin{array}{l}\text { Subject } \\
\text { Affixes in the } \\
\text { Perfective }\end{array}$ & $\begin{array}{l}\text { Sedentary: } \\
\text { katab-t } \\
\text { ktab-t } \\
\text { ktib-t } \\
\text { (Șalālah) }\end{array}$ & $\begin{array}{l}\text { Sedentary: } \\
\text { katab-na } \\
\text { ktab-na } \\
\text { ktib-na } \\
\text { (Șalālah) }\end{array}$ & $\begin{array}{l}\text { Sedentary: } \\
\text { katab-ti } \\
\text { ktab-ti } \\
\text { ktəb-ti } \\
\text { (Șalālah) }\end{array}$ & $\begin{array}{l}\text { Sedentary: } \\
\text { katab-tin } \\
\text { katab-tan } \\
\text { ktab-tin } \\
\text { ktab-tan } \\
\text { ktəbt-en } \\
\text { (Ṣalālah) }\end{array}$ & $\begin{array}{l}\text { Sedentary: } \\
\text { katb-it } \\
\text { katab-it } \\
\text { katb-at } \\
\text { kutb-et } \\
\text { (Ṣalālah) }\end{array}$ & $\begin{array}{l}\text { Sedentary: } \\
\text { katb-in } \\
\text { katb-an } \\
\text { ktab-in } \\
\text { kutb-en } \\
\text { (Șalālah) }\end{array}$ \\
\hline
\end{tabular}


Omani Arabic: More than a Dialect

\begin{tabular}{|l|l|l|l|l|l|l||}
\hline & Bedouin: & Bedouin: & Bedouin: & Bedouin: & Bedouin: & Bedouin: \\
ktab-t & ktab-na & ktab-ti & ktab-tan & ktab-it & ktib-an \\
kitab-t & kitab-na & kitab-ti & kitab-tan & (i)ktib-at & ktab-an \\
& kitab-it & kitab-ni & ktab-tay & & kitb-at & katb-an \\
& (Suwaiq) & kitab-tay & & katb-at & (Suwaiq) \\
& & & (Suwaiq) & & (Suwaiq) & \\
\hline
\end{tabular}

Table 14 presents some of the active participial subject and object suffixes. ${ }^{(1)}$ As Holes (2007) points out, -in(n) is infixed if the participle has verbal force. If it is used as a noun, the infix is not used, e.g. Ali mSallminn-oh 'Ali has taught him' vs. Ali mYallm-oh 'Ali is his teacher'. There are, however, some OA dialects where this infix is not used, as in the DSD form; see also Holes (2011) for a discussion of this morpheme.

Table 14. Participial Subject and Object Affixes

\begin{tabular}{|l|l|l|l|l||}
\hline & $\begin{array}{l}\text { Bāṭina and } \\
\text { Muscat }\end{array}$ & $\begin{array}{l}\text { Northern Mountains } \\
\text { Sedentary Dialects }\end{array}$ & DSD & Bedouin \\
\hline $\begin{array}{l}\text { Masculine Subject and } \\
\text { Masculine Object }\end{array}$ & $\begin{array}{l}\text { kātb-inn-oh } \\
\text { kātb-inn-eh }\end{array}$ & kātb-inn-uh & kātb-u(h) & $\begin{array}{l}\text { kātb-inn-eh } \\
\text { kātb-inn-əh } \\
\text { (Suwaiq) }\end{array}$ \\
\hline $\begin{array}{l}\text { Masculine Subject and } \\
\text { Feminine Object }\end{array}$ & kātb-in-ha & kātb-in-ha & kātib-ha & $\begin{array}{l}\text { kātb-in-ha } \\
\text { kātb-in-hi } \\
\text { (Suwaiq) }\end{array}$ \\
\hline $\begin{array}{l}\text { Feminine Subject and } \\
\text { Masculine Object }\end{array}$ & $\begin{array}{l}\text { kātib-t-inn-oh } \\
\text { kātib-t-inn-eh }\end{array}$ & $\begin{array}{l}\text { kātb-it-n-oh } \\
\text { kâtbit-inn-uh }\end{array}$ & kātb-āt-u(h) & $\begin{array}{l}\text { kātib-t-inn-eh } \\
\text { kātib-t-inn-əh } \\
\text { (Suwaiq) }\end{array}$ \\
\hline $\begin{array}{l}\text { Feminine Subject and } \\
\text { Feminine Object }\end{array}$ & $\begin{array}{l}\text { kātib-t-in-ha } \\
\text { kātbit-in-ha }\end{array}$ & kātb-it-in-ha & kātb-āt-ha & $\begin{array}{l}\text { kātib-t-in-ha } \\
\text { kātib-t-in-hi } \\
\text { (Suwaiq) }\end{array}$ \\
\hline
\end{tabular}

\subsection{The passive form}

The apophonic passive (internally derived by transfixing the vowels $u-i$ in SA) was documented in Reinhardt (1894). A century later, Holes (1998) documents examples from three sedentary OA dialects, those spoken in Wādi Sahtan, Al-Mudaybi, and Qalhāt. The

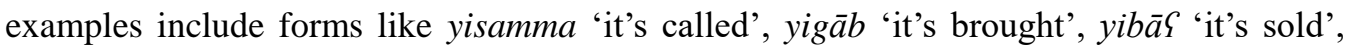

(1) This is when the subject is singular; when it is plural, dialects vary. According to Holes (2007), the plural masculine participial form is kätbinn-uh. Nonetheless, this consonant doubling, though present in other sedentary varieties, does not take place in my BSD variety, where the form is kätbin-oh. 
and yitlag-an 'they (camels) are released'. Eades (2009b) finds examples of the apophonic passive in the Bedouin dialect of the Hidyīwī tribe in the town of Al-Mudaybi, as in yiyāb 'is brought', ðibћat 'was slaughtered', yitayyan 'clay is applied', and yišabb 'set on fire'. A brief survey indicates that the internal passive is available in many Omani cities and towns in central Oman (as also pointed out by Holes p.c.), as in Samāyil (y-qalla 'it's fried', $y i-t$ Tam 'it's fed'), Al-Hamra ( $y$-wadda 'it's taken', $y$-sawwa 'it's made'), Nizwa (yi-țan 'it's ground', $y$-\{allaq 'it's hung'), Naxal ( $y$-\{aqq 'it's thrown', $y$-șallaћ 'it's repaired', $y$-šarrax 'it's torn'), Snāw ( $y$-șabb 'it's poured', yi-šwa 'it is grilled', t-qaș̣ 'it is cut', $y$-ākal 'it is eaten'), and Manaћ ( $y i$-trak 'it's left', $y$-šall 'it's carried', $y$ - $x \bar{a} z$ 'it's removed).

Besides the apophonic passive, many OA dialects use verb Forms V and VII to express the passive, depending on the number of consonants in the root. If the verb is trilateral, like katab 'write', its passive is formed by prefixing Pin- to it (Form VII), as in Pin-katab; the passive of ðarab 'hit' is Pin-ðarab. If the verb is trilateral-plus, whether by gemination like wazzaS 'distribute' or quadrilateral, the passive is expressed by prefixing $t$ - to the stem

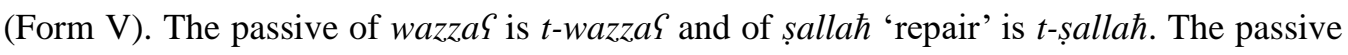
of quadrilateral stems like dahrag 'roll' is t-dahrag, and of kahrab 'electrify' is t-kahrab.

The passive of superficially bi-consonantal stems like šara 'buy' and qara 'read' is expressed by prefixing Pin-, giving Pin-šara and Pin-qara, respectively, or by the passive participle, mašrāy and maqrāy, respectively, the latter strategy being common in the OA sedentary dialects (Holes, 2014). The passive of trilateral stems with a long vowel, like

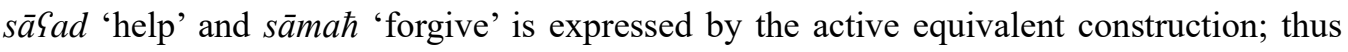
the passive of $s \bar{a} S a d$ is $\hbar a d d s \bar{a} S d-o h$ 'someone helped him', or alternatively by the active participle with object pronominal agreement, as in $m s \bar{a} s d \bar{i} n$-oh 'he has been helped'. Shaaban (1977) also notes that the passive is also expressed by a combination of the copula stawa 'became' and the passive participle form of the verb, so 'was cut' is stawa maqtū $\uparrow$, literally 'became cut'. He states that his consultants accepted the non-apophonic OA passive forms to mean 'got + past participle' rather than 'was + past participle'. I accept this judgment.

\subsection{Other verbal forms}

This section presents how the future, the causative, the imperative, and the intensified forms of the verb are formed in OA. Many OA dialects mark futurity on the verb by prefixing $h a$ - to the imperfective stem; Egyptian Arabic has $\hbar a$-. Thus the future of katab 'write' is ha-yi-ktib, and the future of nām 'sleep' is ha-y-nām. BSD as well as other dialects marks futurity with the prefix $b a$-, thus the future of $k a l$ 'eat' is $b a-y \bar{a}-k i l$, and the 


\section{Omani Arabic: More than a Dialect}

future of qara 'read' is ba-yi-qra. ${ }^{(1)}$ Besides, some northern mountains dialects (sedentary) use $? a-$, as in mata ?a-t-sēr-o 'when will you go?'.

A rare pattern of causation in OA follows SA in doubling the middle consonant (Form II). Thus the causative of katab is kattab, and of qara is qarra. Nonetheless, most OA dialects express causation by combining verbs with the causative verb xalla 'make'. Thus the causative of $s \bar{a} q$ 'drive' is sawwaq in some dialects and xalla-ah y-sūq 'made him drive' in many others; the causative of rakab is xalla-ah yi-rkab 'made him ride'. Different OA dialects have different causative forms; while some have nawwam and qawwam for nām 'sleep' and qām 'stand up', respectively, others have nayyam and qayyam.

The imperative verb in all the OA varieties has lost the affix ?V- of SA, which is $? u$ - if

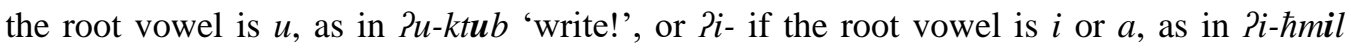
'carry!' and 2i-lSab 'play!', respectively. The imperative form of katab 'write' in both Bedouin and sedentary OA dialects is ktib, except for DSD where it is ktob. Some of these dialects may have the $2 i$ - prefix only in careful formal speech. ${ }^{2}$ The imperative of $q \bar{a} l$ 'say' is $q \bar{u} l$ and $k \bar{u} l$ in the sedentary dialects, but $g \bar{u} l$ and $g a l$ in the Bedouin dialects.

Also, partial reduplication is used for the purpose of intensification. For example, y-miss 'touch' becomes $y$-massis or even $y$-masmis to mean 'touch a lot/on purpose'; $y$-hiss 'feel' becomes $y$-hassis 'to feel by touching' or even 'to be sensitive'; $y$-hizz 'to rock' becomes $y$-hazhaz to mean 'to rock/shake continuously'; $y$-farr 'throw/flip' becomes $y$-farfar to mean 'flip quickly/continuously'.

\section{Syntax}

\subsection{Word order}

Like many other modern dialects, as well as SA, OA allows both the VSO and SVO orders, as (7-8) respectively show. Unlike SA, and like many modern dialects, OA verbs surface with full subject agreement (person, gender, and number) marking in both orders.
(7) katb-inn-oh
1-banāt
1-wāgib
Pst.write-3pf-3sm
the-girls.Nom
the-homework.Acc
'The girls wrote/have written the homework.'
$\begin{array}{lll}\text { (8) 1-banāt } & \text { katb-inn-oh } & \text { 1-wāgib } \\ \text { the-girls.Nom } & \text { Pst.write-3pf-3sm } & \text { the-homework.Acc }\end{array}$

\footnotetext{
(1) On the various functions of the $b$ - prefix in the Gulf dialects, including OA, see Persson (2008) who argues that it is "a generalized marker of the irrealis mood" (p. 26) that also denotes futurity.

(2) See the imperative verb forms of MD in Glover (1988:182).
} 


\section{Rashid Al-Balushi}

'The girls wrote/have written the homework.'

Al-Aghbari (2004b), who is a native speaker of MD, points out that SVO is more frequent than VSO in daily conversation, ${ }^{1}$ and that objects never surface sentence-initially in OA, as (9-10) show. While these observations are also true of BSD and DSD, thematic objects can surface sentence-initially, but as left-dislocated elements, as (11-12) show, dislocation being signaled by the resumptive pronoun on the verb.
(9) *kum-t-oh Ali fasax cap-f-his Ali.Nom
Pst.take.off.3sm
(10) *kum-t-oh cap-f-his
fasax
Ali
Pst.take.off.3sm
Ali.Nom
(11) ș-ṣyēr-īn
Pumm-hum
ð̣arb-it-hum
the-child-p.Nom
mother.Nom-their.m
Pst.hit-3sf-3pm
'The children, their mother hit them.'
(12) ș-ṣyēr-īn Jụb-it-hum Pumm-hum
the-child-p.Nom Pst.hit-3sf-3pm mother.Nom-their.m
'The children, their mother hit them.'

Like those of other colloquial Arabic dialects, OA nouns do not carry morphological case. Despite this, I will assume that they carry the same Case values that their SA counterparts realize. Also, like those of most modern Arabic dialects, OA singular nouns have largely lost the final - $n$, so-called tanwīn/nunation. Nonetheless, remnants of tanwīn can be seen in the slow sophisticated speech of some especially Bedouin dialects, as (13-14) illustrate, as well as in poetry, on this, see Holes $(2013,2014)$.
(13) štarē-na
Pst.buy-1p
'We bought a new car.'
siyyār-t-in
gdīd-ah/-t-in
car.Acc-f-Nu
new.Acc-f/-f-Nu
(14) Salim Gind-eh bGīr-in rakkāộ-in
Salim.Nom with-him male.camel.Nom-Nu running.Nom/-Nu
'Salim has a fast-running male camel.'

In addition to full subject agreement, OA verbs realize full object agreement marking in both orders and in the presence of a lexical DP object, as (15-16) show; this is also shown in (7-8). Thus OA differs from SA, where object agreement does not co-exist with a lexical object, as the contrast between (17) and (18) illustrates.
(15) katb-ū-hin
1-?awlād
wāgb-ā-t-hum

(1) This contrasts with the situation in Egyptian Arabic, which is predominantly VSO (Tucker, 2010:8). 


\section{Omani Arabic: More than a Dialect}

Pst.write-3pm-3pf the-boys.Nom homework.Acc-p-f-their.m

'The boys wrote/have written their homework.'
(16) 1-Pawlād
katb-ū-hin
wāgb-ā-t-hum
the-boys.Nom Pst.write-3pm-3pf
homework.Acc-p-f-their.m
'The boys wrote/have written their homework.'
Pst.write.3sm-3sf the-boys-Nom homework-p-f-Acc-their.m
(18) kataba-hā 1-Pawlād-u
Pst.write.3sm-3sf the-boys-Nom
'The boys wrote/have written them.f.'
(17) *kataba-hā $\quad$ l-Pawlād-u $\quad$ wājib-ā-t-i-hum $\quad$ SA

\subsection{Negation}

This section surveys the negative particles used in various OA dialects. The negation system in the OA dialects is quite rich, which calls for a theoretical analysis. Most dialects use $m \bar{a}$ in deictic, generic/habitual, past tense, future time, verbless sentences, and tenseless conditionals, as (19-24) respectively show; these examples are from BSD.
(19) Ahmad mā yi-ktib l-wāgib
Ahmad.Nom Neg Impf-write.3sm the-homework.Acc
'Ahmad is not writing the homework.'
(20) mā yi-ktib
Ahmad
wāgb-ā-t-oh
Neg Impf-write.3sm Ahmad.Nom
homework.Acc-p-f-his

'Ahmad does not write his homeworks.'
(21) Ahmad mā rāh 1-madrasah
Ahmad.Nom Neg Pst.go.3sm the-school.Acc

'Ahmad did not go to school.'
(22) Ahmad mā ba-y-rūh 1-madrasah
Ahmad.Nom Neg Fut-Impf-go.3sm the-school.Acc
'Ahmad will not go to school.'
(23) Ahmad mā mariōọ
Ahmad.Nom Neg sick

'Ahmad is not sick.'
(24) Piðā mā t-ðākər ba-ti-sqat
if Neg 2-study.sm Fut-2-fail.sm

'If you do not study, you will fail.'

The Dhofāri dialects also have the negative particle $m \bar{u}$ and the enclitic $-\check{s}$, as (25-26) 


\section{Rashid Al-Balushi}

from DSD show; (26) shows that a sentence may have two negative elements; this is also observed in other Arabic dialects, like Egyptian and Moroccan. The $-\check{s}$ Neg enclitic in DSD may also appear as a free morpheme, as in (27-28). ${ }^{11}$

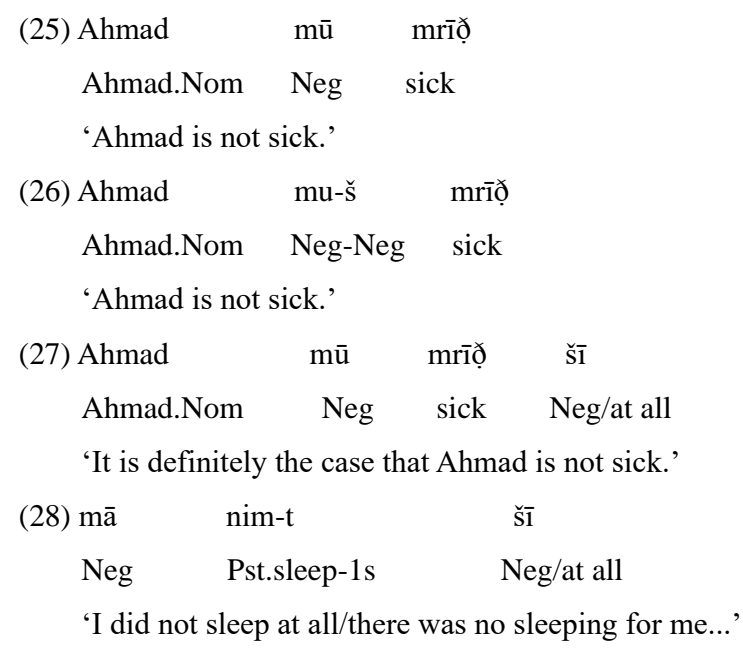

The eastern (Bedouin) dialects use $? a-b, m a-b, m a-h u$, and $m a-h u-b$, as (29-33) show. Given comparison with negative particles used in northern Oman (sedentary) dialects (to be discussed shortly), $? a-b$ seems to be composed of the Neg particle $? a$ - and the suffix $-b$,

\footnotetext{
(1) These data may suggest that $s ̌ \bar{l}$ is a grammaticalized form of the noun $s_{\bar{l}}$ 'thing' in the Dhofāri dialects ( $\check{s}$ ay? in SA), used to negate the applicability/truth of the predicate (the negation of the predicate is asserted). This proposal, however, will have to account for negative sentences in other OA dialects (sedentary northern) where $-\check{s}$ appears without a negative particle, but doubled, as in (i-ii). I leave this here; $\check{s}$ ay may also serve as an existential quantifier, as in (iii).

(i) šn-šsi yanim

thing-Neg goats

'Are there no goats?'

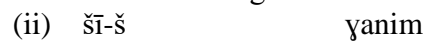

thing-Neg goats

'There are no goats.'

(iii) mā šay siyyār-ā-t

Neg thing car-p-f

'There are no cars.'

This $-\check{s}$ enclitic, which also appears in Moroccan Arabic, as in (iv), couples with the Neg particle ma-. Unlike Moroccan Arabic, the sedentary northern variety of OA may establish negation without $m a-$, as (v) shows.

(iv) ma-mSallim-š

Neg-teacher/teaching-Neg

'I am not a teacher/teaching (at all).'

(v) Pa-Sraf-š

1s-know-Neg

'I do not know/I know nothing (at all).'
} 
which seems to be a negative polarity item (NPI); ${ }^{(1)}-b$ is also used in some Gulf dialects, as (34) from Kuwaiti Arabic shows; ? $a-b$ also appears in expressions like ?a-b kih and $? a-b$ $k \bar{a} k$ '(it is) not like this/not like that'. The Bāṭina Bedouin dialects also have $m u$ and $m a-h u$; $-h u$, which is also seen in other negative particles in other dialects (to be discussed soon), seems to be a pronominal (SA huwa), sometimes with copular functions. ${ }^{2}$ Another Bedouin variety spoken by Al-Magৎali tribe (a branch of the Al-Junaibi tribe) in the town of Manah in the interior, a typical region for sedentary varieties, uses another particle, ?am, as in (35-36).
(29) Ahmad Pa-b hnīh
Ahmad.Nom Neg-NPI here
'Ahmad is not here.'
(30) Pa-b Ahmad hnīh

Neg-NPI Ahmad.Nom here
'It is not Ahmad who is here.'

$\begin{array}{llll}\text { (31) s-sayyāra-h } & \text { ma-b/mā-b } & \text { zēn-ah } & \text { alћīn } \\ \text { the-car.Nom-f } & \text { Neg-NPI } & \text { good-f } & \text { now }\end{array}$
'The car is not good now.'
(32) Ahmad ma-hu/mu-hu mariộ
Ahmad.Nom Neg-pron sick
'Ahmad is not sick.'
(33) Ahmad ma-hu-b/mā-hu-b marīọ
Ahmad.Nom Neg-pron-NPI sick
'Ahmad is not sick.'
(34) Ahmad mu-b marīọ
Ahmad.Nom Neg-NPI sick
'Ahmad is not sick.'
(35) Pam rāyh-ah maS-ik
Neg going-sf with-you.sf
'I am not going with you.sf.'

\footnotetext{
(1) The suffix $-b$ in the Bedouin OA dialects seems to have a cognate in SA, the prepositional element prefixed to the predicate in (i), licensed by the negative particle $m \bar{a}$.

(i) mā Pat-tālib-u bi-mujtahid-in

Neg the-student-Nom NPI-hardworking-Gen

'The student is not hardworking.'

(2) Eid (1983), among others, argues that pronouns in Egyptian Arabic have copular functions.
} 


\section{Rashid Al-Balushi}

$\begin{array}{lcll}\text { (36) Ahmad Pam } & \text { māši } & \text { Palhīn } \\ \text { Ahmad.Nom Neg } & \text { going.sm } & \text { now } \\ \text { 'Ahmad is not going now.' } & \end{array}$

In addition to $m \bar{a}$, one northern mountains sedentary dialect has $-\check{s}$, as a Neg particle (enclitic), which must be phonetically attached to some element as (37-39) show. In (39-40), $-s ̌$ is attached to the future morpheme/particle $h a$-, that $h a$ - marks futurity is shown by (41). This is also supported by the ungrammaticality of (42) which has two future morphemes, as well as that of (43) since adjectives are not marked for tense/time.

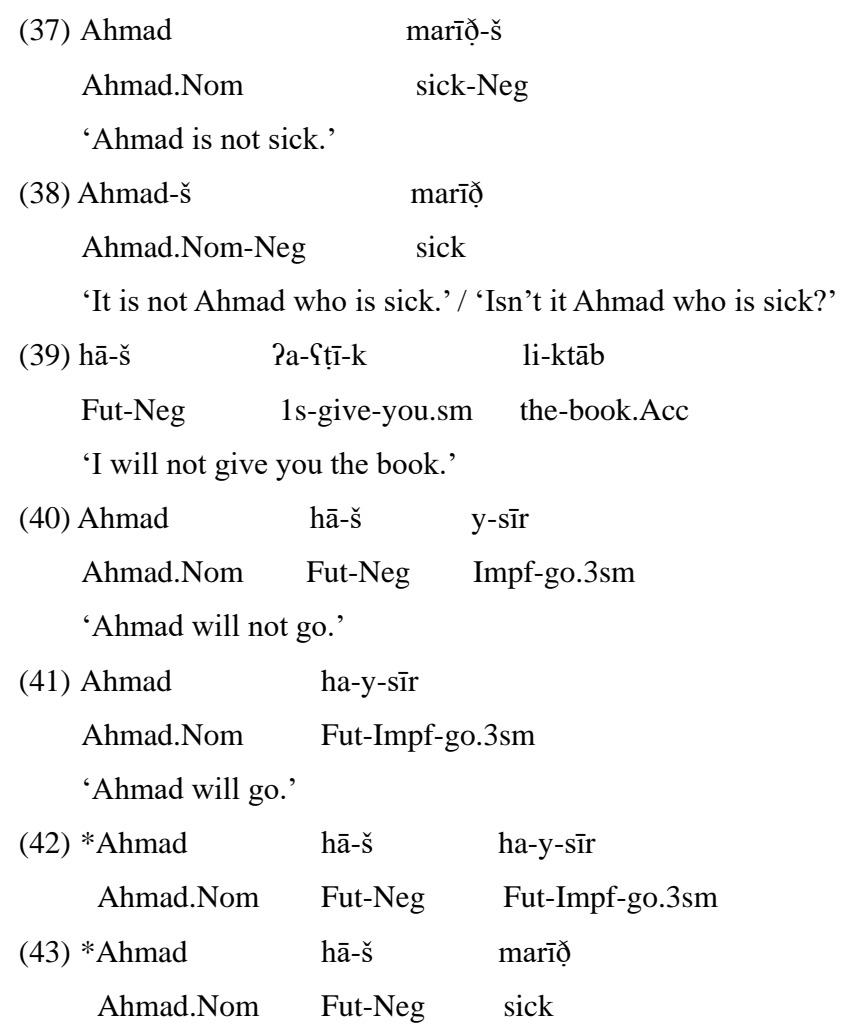

The yes/no question negative particle in this northern sedentary dialect is ho-?oh, as (44) shows; ho-?oh seems to be composed of the pronominal ho- and the Neg particle -?oh (which corresponds to the Neg particle ?a- seen in the eastern Bedouin dialects), where hoarguably comes from the first syllable of the $3^{\text {rd }}$ person pronouns in Arabic. Thus (44) may be translated as 'Is Ahmad sick? he-not', where ho may have copular functions. This

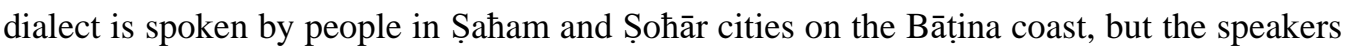
originally come from the northern mountains of Oman. 


\section{Omani Arabic: More than a Dialect}

$\begin{array}{lll}\text { (44) Ahmad } & \text { mrīọ? } & \text { ho-?oh } \\ \text { Ahmad.Nom } & \text { sick } & \text { pron-Neg } \\ \text { 'Is Ahmad sick? } & & \text { No/he's not.' }\end{array}$

Besides, another northern sedentary dialect has the Neg particle $h \bar{a}-? a h / h \bar{a}-\{o h$, which does not appear in sentential negation, but only in replies to yes/no questions, as (45) shows; $h \bar{a}-? a h$ and $h o$-?oh may well be the same element; $m \bar{a}$ is used for sentential negation in this dialect. The particle $h \bar{a}-\mathrm{P} a h$, too, seems to be composed of two elements, $h \bar{a}-$, the pronominal element, and the Neg particle -?ah, which is found in the eastern

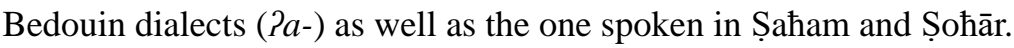
(45) Ahmad mrīọ?
hā-?ah/hā-?oh
Ahmad.Nom
sick
pron-Neg
'Is Ahmad sick?
No/he's not'

The Šiłhi OA dialect exhibits a different negation pattern, as (46) shows, where the Neg particle follows the predicate; (46) can also take the same structure observed in the other OA dialects, as (47) shows. The structure in (46) is more common among older generations. With a verbal predicate, as in (48), the Neg particle could be either one, but only $l \bar{a}$ can follow the verb, as (49) shows.

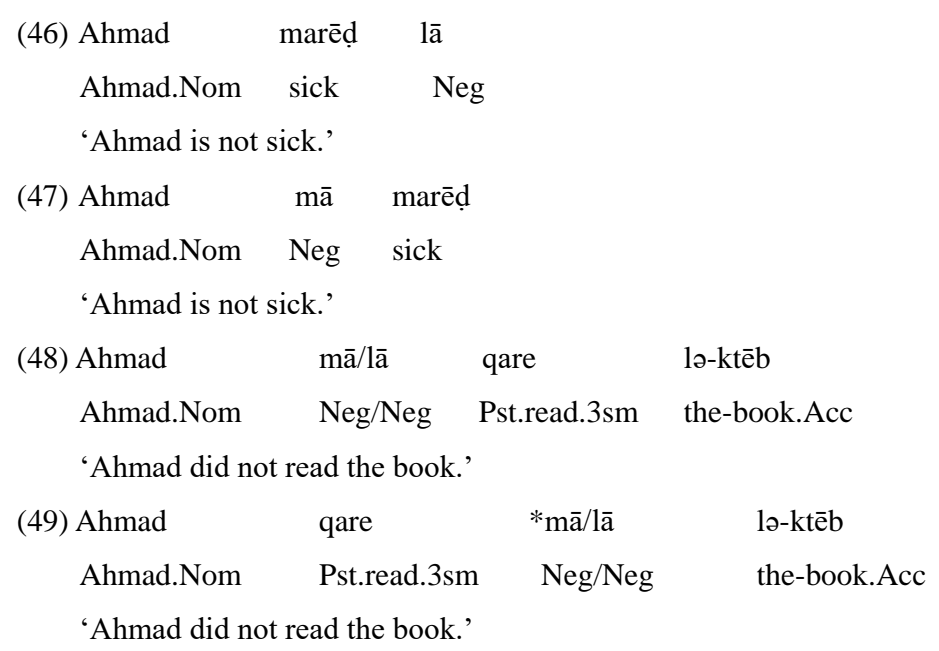

As for negative imperatives, while most OA dialects use the prohibitive particle $l \bar{a}$, others, like the northern sedentary dialects, use $m \bar{a}$ and $\mathcal{A} a n$, as (50) shows, and yet others use a more elaborate/assertive form, as in (51). The Šiћћi dialect uses the structure in (50) with $l \bar{a}$ only as well as the one in (52), with two occurrences of the Neg $l a$.
(50) $1 \bar{a} / \mathrm{ma} / \Upsilon_{\text {an }}$
t-kitb-u
ৎa lə-gdār 


\section{Rashid Al-Balushi}

Neg.Impr 2-write-pm on the-wall.Gen

'Don't (you.pm) write on the wall!'

$\begin{array}{lllll}\text { (51) San } & \text { t-b-u } & \text { t-kitb-u } & \text { ९a } & \text { lo-gdār } \\ \text { Neg.Impr } & \text { 2-want-pm } & \text { 2-write-pm } & \text { on } & \text { the-wall.Gen }\end{array}$

'Don't (you.pm) even attempt to write/think about writing on the wall!'
(52) ti-ktib
la ?a lo-gdōr
la
2-write.sm Neg on the-wall.Gen $\mathrm{Neg}$
'Don't (you.sm) write on the wall!'

As indicated earlier, this paper will not include a theoretical account of these facts; this is left for another venue. Now, we move to question formation.

\subsection{Question formation}

Like SA as well as the other dialects of Arabic, OA varieties exhibit wh-movement (to Spec, CP) in forming wh-questions, as (53-56) show.
(53) $\min$
kal
1-mōzah?
who Pst.eat. $3 \mathrm{sm}$
the-banana.Acc
'Who ate the banana?'
(54) mū kal-u
what Pst.eat-3pm
'What did they eat?'
(55) wēn haṭē-t lə-ktāb
where Pst.put-2sm the-book.Acc
'Where did you put the book?
(56) mita ba-y-gi Ahmad
when Fut-Impf-come.3sm Ahmad.Nom
'When will Ahmad come?'

Besides wh-movement, OA forms wh-question in-situ, as (57) shows. When the wh-question is embedded under an ECM predicate, the wh-word may stay in-situ, or undergo wh-movement to the embedded Spec, CP, or even to the matrix Spec, CP, as (58-60) respectively show.
(57) kal-u mūh
Pst.eat-3pm what
'What did they eat? / They ate what?'
(58) ti-Gtiqid [ṣ-ṣyēr-īn kal-u ?eš $]$
2-believe.sm the-children.Nom Pst.eat-3pm what




\section{Omani Arabic: More than a Dialect}

'What do you believe the children ate?'

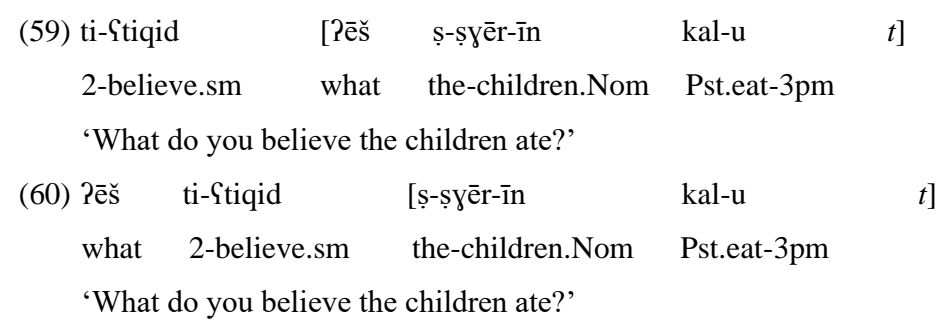

OA does not have the SA yes/no question particles, hal and the bound morpheme ?a-. Holes (2007:8) mentions some particles that feature in some northern mountains varieties, like $\check{s} a y / s ̌ i$ and the clitic $-\partial$, as well as the tag-question particle $l \bar{a}$ (or $l \bar{a} h$ ) when attached to the end of a sentence, as (61-62) show.
(61) qūm-i
gīb-ī-h,
Š̀
Impr.get.up-sf Impr-bring-sf-it, Interro.Neg
'Get up and bring it, won't you?'
(62) Pabū-k ba-y-gī, lāh
father-your Fut-Impr-come.3sm, Interro.Neg
'Your father is coming, no/isn't he?'

For most OA dialects, the declarative sentence in (63) and the interrogative one in (64) seem to have the same structure, the difference being only in intonation.
(63) qafl-it
l-bāb
Pst.lock-3sf the-door.Acc
'She locked/has locked the door.'
(64) qafl-it 1-bāb
Pst.lock-3sf the-door.Acc
'Did she lock/Has she locked the door?'

While most OA varieties use naSam (SA yes) as a positive reply to yes/no questions, some dialects use hēh, hīh, whereas others use hêwah and Paywa, and yet others use $2 \bar{e}(h)$ and Pilla. Holes (2007) also mentions $\bar{\imath}, \bar{e}, k \bar{e}, i l a, h i$, and $\bar{e}$ naSam. Negative replies include

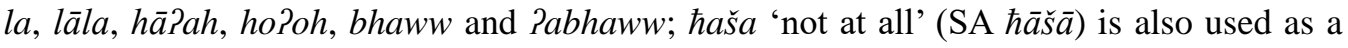
stronger form of negation.

\subsection{Relative clauses}

Unlike SA, whose relative pronouns inflect for number, gender and case, the OA dialects have two relative pronouns, Pilli and $b u$, which do not inflect; Holes (2007:7), who states that $b u$ is more common in sedentary varieties, also mentions illaði, which is the SA one 


\title{
Rashid Al-Balushi
}

(?allaði), as well as $i l$, which is like a contracted form of Pilli. Both Pilli and bu carry the default agreement specification, $3^{\text {rd }}$ person singular masculine; (65-68) provide examples of Pilli and $b u$. ${ }^{1}$
(65) ga
1-walad
Pilli/bu
Pa-Yarf-oh
Pst.come.3sm the-boy.Nom
whom/whom
$1 \mathrm{~s}-\mathrm{know}-3 \mathrm{sm}$
'The boy whom I know came.'
(66) g-u$$
\text { l-walad-ēn/ 1-Pawlād }
$$
Pilli/bu nagh-u
Pst.come-3pm the-boy-d.Nom/the-boys.Nom
who/who Pst.succeed-3pm
'The two boys/boys who succeeded came.'
(67) gā-t
1-bint
Pilli/bu
Pa-Yarf-ha
Pst.come-3sf
the-girl.Nom
whom/whom
1s-know-3sf
'The girl whom I know came.'
(68) g-in
1-bint-ēn/
1-banāt
Pilli/bu nagh-in
Pst.come-3pf the-girl-d.Nom/the-girls.Nom who/who
Pst.succeed-3pf
'The two girls/girls who succeeded came.'

As for $b u$, it seems to be a grammaticalization of the SA noun meaning 'father', ?abü; (69) is a question addressed to me by a sedentary dialect speaker from Suwaiq on the Bāṭina coast.
(69) bēt-ak

$$
\text { Pabu fi lmaßbēleh zahab? }
$$$$
\text { house-you which in Mabela Pst.complete.3sm }
$$
'Your house, which is (you are building) in Mabela, is it completed/ready?'

Besides, Prophet Muhammad (pbuh) nicknamed one of his companions (Gabdur-Rahmān bin Șaxr Pad-dūsī) Pabū Hurayrah (the one with a cat) because that companion used to carry a small cat around and play with it during the day-time. SA has another pronoun which can be used in relative clauses, $\partial \bar{u}$, as (70) shows. ${ }^{2}$
(70) Par-rajul-u ðū 1-qubbaSat-i
ya-ṭlub-u
1-bītzā
the-man-Nom that.has the-hat-Gen
Impf-order.3sm-Ind
the-pizza.Acc
'The man in the hat has ordered a pizza.'

\begin{abstract}
(1) SA has the following relative pronouns, from Wright (1896:270-272); the underlined forms are archaic for Nom-marked relative pronouns.

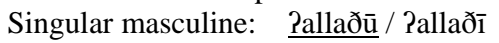
Dual masculine: $\quad$ Pallaðāni / Pallaðayn
Singular feminine: Pallatī
Plural masculine:
Pallaðūna / Pallaðīna
Dual feminine: Pallatāni/Rallatayni
Plural feminine: Pallātī or Pallā? $\overline{1}$

(2) Arabicists know that $P a b \overline{\boldsymbol{u}}$ and $\partial \overline{\boldsymbol{u}}$ are members of the so-called Pal-Pasmā?-u l-xamsah 'the five nouns',

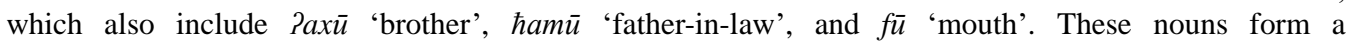
homoegenous group because they are Nom-marked with $-\bar{u}$, Acc-marked with $-\bar{a}$, and Gen-marked with $-\bar{l}$.
\end{abstract}




\section{Omani Arabic: More than a Dialect}

SA $\partial \bar{u}$ can be $2 a b u$ (SA 'father') and ?umm (SA 'mother') in OA, depending on the gender of the possessee, as (71-72) show.

$\begin{array}{rllll}\text { (71) ðāk } & \text { r-riggāl } & \text { Pabu } & \text { 1-mṣar } & \text { lə-ћmar } \\ \text { that } & \text { the-man } & \text { of } & \text { the-turban } & \text { the-red }\end{array}$

'That man in the red turban.'

$\begin{array}{lllll}\text { (72) đīk } & \text { l-bint } & \text { Pumm } & \text { Pəl-Yyūn } & \text { z-zarqa } \\ \text { that.f } & \text { the-girl } & \text { of } & \text { the-eyes } & \text { the-blue }\end{array}$

'That girl who has blue eyes.'

\subsection{Tense, aspect, and mood}

OA verbs exhibit almost the same tense and aspect denotations that SA verbs have. For example, the so-called perfective form conveys past tense as well as the English present perfect interpretation, as (73) shows. ${ }^{(1)}$ The so-called imperfective paradigm verbs convey both deictic and generic interpretations, depending on word order (as well as on whether the verb is eventive or stative). In the SVO order, the imperfective verb conveys deictic interpretation, as (74) shows. It conveys a generic (habitual) reading in the VSO order, as (75) shows; these examples are from BSD.

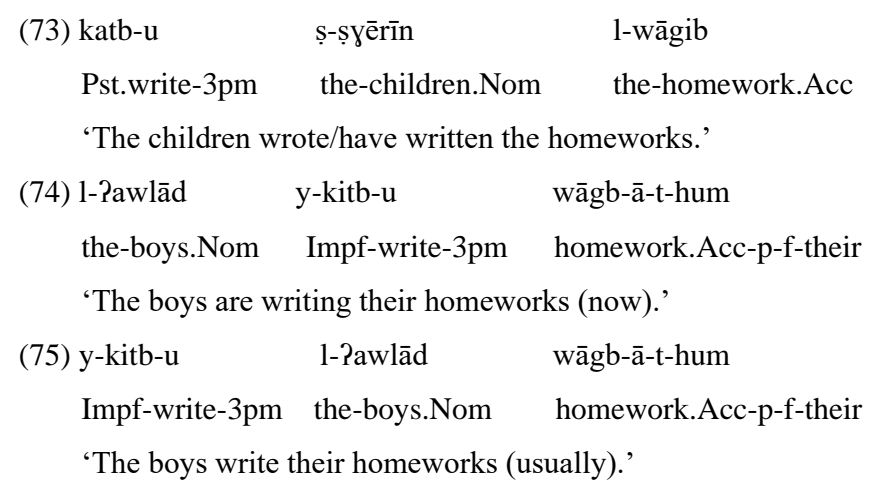

The deictic reading corresponds to the progressive aspect, which can also be conveyed by a special progressive morpheme, as in (76). The progressive morpheme is the active participle form of the verb galas 'to sit', which is gālis. The Dhofāri dialects use a bound morpheme to indicate progressive aspect, as in (77); this morpheme is also available in Egyptian Arabic, as (78) shows. The imperfect aspect is also conveyed by a special free morpheme baSad 'still/yet', as (75) shows.
(76) 1-?awlād
gāls-īn
y-kitb-u
wāgb-ā-t-hum

\footnotetext{
(1) For tense, aspect, and mood in some OA varieties, see Eades (2012), Eades and Watson (2013), and Persson (2008).
} 


\section{Rashid Al-Balushi}

the-boys.Nom Prog-pm Impf-write-3pm homework.Acc-p-f-their

'The boys are (in the process of) writing their homework.'

(77) nahnā b-nā-kul

we Prog-1p-eat

'We are eating (right now).'

(78) Pihna b-nā-kul Pahoh

we Prog-1p-eat here.and.now

'We are eating right now (see!).'

$\begin{array}{lllll}\text { (79) 1-Pawlād } & \text { baSad-hum } & \text { mā } & \text { katb-ū } & \text { wāgb-ā-t-hum } \\ \text { the-boys.Nom } & \text { yet/still-3pm } & \text { Neg } & \text { Pst.write-3pm } & \text { homework. Acc-p-f-their }\end{array}$

'The boys have not yet written their homeworks.'

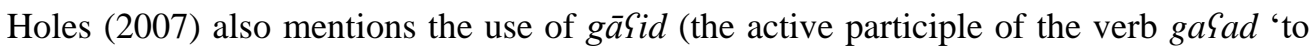
sit' in other, usually Bedouin, OA varieties; SA qaৎada) as a means for expressing continuous or iterative processes; $g \bar{a}$ sid is found in many Gulf varieties, as in (80) from Kuwaiti Arabic. The perfect aspect can be conveyed by a free morpheme, xallas 'done/finished', followed by the active participle form, as in (81).

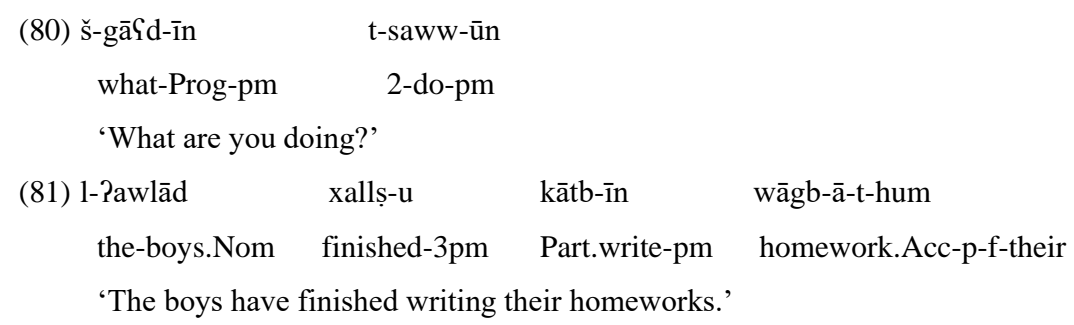

OA verbs also convey the so-called prospective aspect, as (82-83) show; rāyih, which is found in the Bātina varieties, and qayyim, which is found in the northern sedentary varieties (interior of Oman), are both the active participle forms of $r \bar{a} \hbar$ 'to go' and $q \bar{a} m$ 'to stand up',

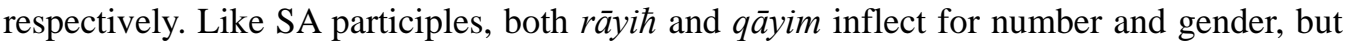
not person. The Bedouin counterpart of (83) is in (84), where the progressive aspect is carried out by the participle. As (85-86) show, both rāyit and qāyim may be the main predicate of a sentence, but with their literal meanings.
(82) hna mā rāyћ-īn nə-qra 1-ktāb 1-yōm
we Neg going-pm 1p-read the-book.Acc the-day
'We are not going to read the book today.'
(83) Pana mā qāyim 1-qra 1-ktāb 1-yōm
I Neg going.sm 1s-read the-book.Acc the-day




\section{Omani Arabic: More than a Dialect}

'I am not going to read the book today.'
(84) Pana mə-b-gāri 1-ktāb 1-yōm
I Neg-NPI-reading the-book.Acc the-day
'I am not going to read/reading the book today.'
(85) Pana rāyiћ s-sūq
I going the-market.Acc
'I am going to the market.'
(86) Pana qāyim mən n-nōm
I going from the-sleep.Gen
'I am getting up (from bed)/ already up.'

The OA varieties differ as to whether their imperfective verb forms inflect for what Wright (1896) calls 'mood' marking. ${ }^{1}$ Singular present tense verbs in all the OA varieties do not carry 'mood' marking; OA varieties lost the dual marking in the verbal system. As for the plural verbal forms, while the verb in the Dhofāri and Bedouin varieties appears with 'indicative mood' marking, as (87-88) show, it does not in the other varieties, as (89) shows.

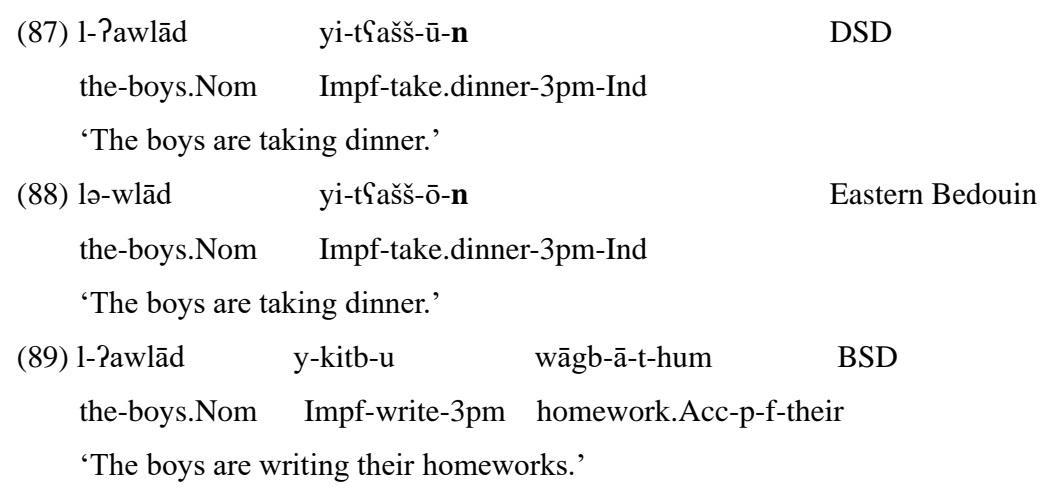

Finally, besides the $b a-, h a-$, and $? a$ - prefixes of the future (discussed in section 4.9), modality in OA is expressed by the particles lāzim 'must' and yimkin 'may/might', as (90-91) show. Other modality particles include $y b \bar{a}-l o h$ and its DSD counterpart byā-loh, which roughly mean 'should', as (92-93) show.
(90) t-țəllāb

$$
\text { lāzim }
$$$$
\text { y-rūh-u }
$$
1-madrasah
the-students.Nom
must
Impf-go-3pm
the-school.Acc
'The students must go to the school.'

\footnotetext{
(1) See Fassi Fehri (1993) and Al-Balushi (2013) for alternative views on what these suffixes mark. 


\section{Rashid Al-Balushi}

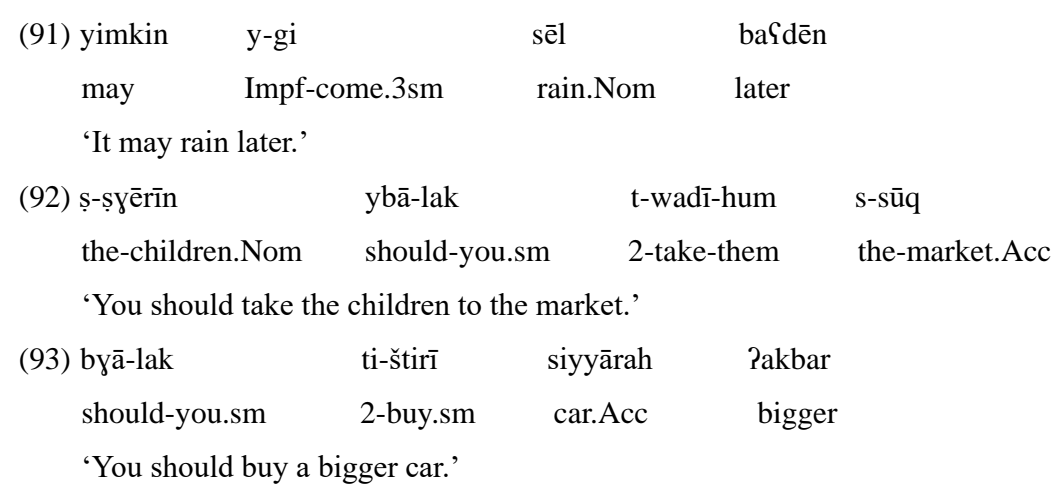

\section{Final remarks}

The preceding sections have shown that the Omani dialect of Arabic is a rich one, having several varieties. The variation, most vividly seen in negation, pluralization patterns, personal, demonstrative, and possessive pronouns, as well as sound interactions, speaks of a productive research program. Most of the research on the OA dialects has been of a descriptive and sociolinguistic nature, which calls for theoretical accounts of these facts.

Theoretical treatment is required for a number of topics. For example, the preference for SVO over VSO in MD may have implications for information structure issues. Also important is the morphosyntactic function of full subject and object agreement on OA verbs, investigated in Al-Balushi (to appear). Equally important is a morphosyntactic analysis of negation in the various OA dialects, as well as the possible copular functions of pronouns. Besides, the various pluralization patterns in OA dialects as well as those of borrowed words may have implications for theories of morphology and phonology. Likewise, it is important to examine the conditions regulating free variation in the phonology of the

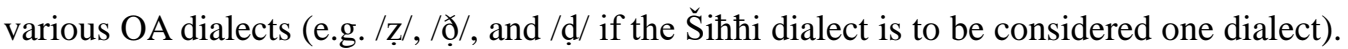
Also important for verb structure is the issue of glide-restoration.

In addition, it is crucial to provide description and documentation of the OA dialects before their distinctive features are lost as a result of convergence and leveling. Also important are the implications of the passive verb form retention for the history of the OA dialects (being older or recent compared to other dialects in Arabia). It is also crucial to provide descriptive accounts of the other languages and Arabic dialects spoken in Oman, as well as theoretical accounts of their syntactic, morphological, and phonological, influences on the OA dialects. It is, for example, recognized that the Baluchi community in Muscat speak a variety of Baluchi slightly different from that spoken on the Bātina coast, which 
indicates that the varieties of Baluchi spoken in Oman may be slightly different from those spoken in Baluchistan (in both Iran and Pakistan); this may also apply to the other languages.

Furthermore, an intriguing sociolinguistic phenomenon is the slow switch from sedentary dialects to Bedouin ones, an observation already made in Holes (2014), witnessed in the televised media in Oman. This may be because of the predominant Gulf and Jordanian drama (aired in the 1980s and 1990s) in which forms of Bedouin dialects are spoken. This, however, is contradicted by the fact that not only is the Omani drama delivered through sedentary dialects (being the dialect of the actors), but also the fact that the royal family in Oman speaks a sedentary dialect; the question is still open nonetheless. On the local social level, it is very common to hear some sedentary dialect speakers pronounce words with Bedouin morphophonological features, where /q/ is pronounced as /g/. The factors conditioning this switch make an interesting question. Also, the similarity between the OA dialects and the pre-Islamic ones can certainly make a very interesting question. Finally, Holes (1989) states that the word for 'coffee' is ghawah and gahwah in Bedouin dialects, but kahwah and qahwah in the sedentary ones. Besides these, ghawwah is heard in the (Bedouin) dialect of Bidiyyah and ghewa is heard in the Dhofāri Bedouin dialect, indicating the existence of other variants in the other towns/varieties. These and other equally interesting topics are left for other occasions.

\section{References}

Al-Aghbari, Khalsa. 2004a. The Broken Plurals in the Muscat Dialect of Omani Arabic [D]. M.A. Thesis, Victoria, Canada: University of Victoria.

Al-Aghbari, Khalsa. 2004b. Word order of wh-questions in Omani Arabic [A]. Working Papers of the Linguistic Circle (WPLC) [C]. Victoria, Canada: University of Victoria.

Al-Balushi, Rashid. 2013. Verbal and Nominal Case Suffixes in Standard Arabic: A Unified Account [J]. Brill's Annual of Afroasiatic Languages and Linguistics, 5(1):35-82.

Al-Balushi, Rashid. To appear. The Relationship between Agreement and Morphological Case: Evidence from Arabic. Concentric: Studies in Linguistics.

Benmamoun, Elabbas, and Mark Hasegawa-Johnson. 2013. How Different are Arabic Dialects from Each Other and from Classical Arabic? [A] The 6th International Arabic Linguistics Symposium [C]. Morocco: Al-Akhawayn University.

Brockett, Adrian. 1985. The spoken Arabic of Khabura on the Bațina of Oman [J]. Journal of Semitic Studies. Monograph 7.

Eades, Domenyk. 2009a. The Arabic dialect of a Shawawi community of northern Oman [A]. In R. D. Jong \& E. A. Wer (eds.), Arabic Dialectology: In honor of Clive Holes on the Occasion of his $60^{\text {th }}$ Birthday [C]. Leiden: Brill. 77-98.

Eades, Domenyk. 2009b. Retention of the Passive Verb in a Bedouin dialect of Northern Oman [J], 


\section{Rashid Al-Balushi}

Journal of Arabic Linguistics, 51(1):5-21.

Eades, Domenyk. 2011. A transitional Arabic dialect of the northern Omani interior, Journal of Arabic Linguistics, 54, 1:27-41.

Eid, Mushira. 1983. The copula function of pronouns [J]. Lingua, 59:197-207.

Fassi Fehri, Abdelkader. 1993. Issues in the Structure of Arabic Clauses and Words [M]. Dordrecht: Kluwer.

Ferguson, Charles. 1959. The Arabic koine [J]. Language, 35(4):616-630.

Galloway, Douglas. 1977. An introduction to the spoken Arabic of Oman [Z]. Ms.

Glover, Bonnie. 1988. The Morphophonology of Muscat Arabic [D]. Doctoral Dissertation. Los Angeles: University of California.

Holes, Clive. 1989. Towards a dialect geography of Oman [J]. Bulletin of the School of Oriental and African Studies, 52:446-462.

Holes, Clive. 1991. Kashkasha and the fronting and affrication of the velar stops revisited: A contribution to the historical phonology of the peninsular Arabic dialects [A]. In Alan Kaye (ed.), Semitic Studies in Honor of Wolf Leslau [C], Vol. 1. Wiesbaden: Harrassowitz. 652-778.

Holes, Clive. 1996. The Arabic dialects of south-eastern Arabia in a sociohistorical perspective [J]. Jounal of Arabic Linguistics, 31:34-56.

Holes, Clive. 1998. Retention and loss of the passive verb in the Arabic dialects of northern Oman and eastern Arabia [J]. Journal of Semitic Studies, 43(2):347-362.

Holes, Clive. 2004a. Modern Arabic: Structures, functions, and varieties [M]. London: Longman.

Holes, Clive. 2004b. Quadriliteral verbs in the Arabic dialects of eastern Arabia [A]. In M. Haak, R. D. Jong \& K. Versteegh (eds.), Approaches to Arabic Dialects: A Collection of Articles presented to Manfred Woidich on the Occasion of his Sixtieth Birthday [C]. Leiden: Brill. 97-116.

Holes, Clive. 2007. Omani Arabic [A]. In Lat-Pu. K. Versteegh, A. Elgibali, M. Woidich, \& A. Zaborski (eds.), Encyclopaedia of Arabic Language and Linguistics [C], Vol 3. Leiden, Boston and Cologne: Brill. 478-491. [corrected attribution is in Encyclopaedia of Arabic Language and Linguistics On-Line Edition, 2011]

Holes, Clive. 2011. A Participial Infix in the Eastern Arabian Dialects - An Ancient Pre-Conquest Feature? [J] Jerusalem Studies in Arabic and Islam, 38:75-98.

Holes, Clive. 2012. The Omani Arabic Dialects in Their Regional Context: Yesterday, Today, and Tomorrow [A]. In N. Zidgaly (ed.), Building Bridges: Integrating Language, Linguistics, Literature, and Translation in English Studies [C]. Cambridge: Cambridge Scholars Press. 233-250.

Holes, Clive. 2013. An Arabic text from Șūr, Oman [A]. In R. D. Jong \& C. Holes (eds), Ingham of Arabia: A Collection of Articles Presented as a Tribute to the Career of Bruce Ingham [C]. Leiden: Brill. 87-107.

Holes, Clive. 2014. The Omani dialects of Arabic [A]. In Oman Encyclopedia [C], prepared by the Ministry of Heritage and Culture in Oman.

Jayakar, Atmaram. 1889. The Omanee dialect of Arabic [J]. Journal of the Royal Asiatic Society, 21:649-889.

Jayakar, Atmaram. 1903. The Shahee dialect of Arabic [J]. Journal of the Bombay Branch of the Royal Asiatic Society, 21:246-277.

Johnstone, Thomas. 1967. Eastern Arabian dialect studies [M]. Oxford: Oxford University Press.

Praetorius, Franz. 1880. Uber den arabischen Dialekt vin Zanzibar [J]. Zeitschrift der deutschen morgenlandischen Gesellschaft, 34:217-231. 


\section{Omani Arabic: More than a Dialect}

Prochazka, Theodore. 1981. The Shi'i dialects of Bahrain and their relationship to the eastern Arabian dialects and the Omani dialect of al-Ristaq [J]. Journal of Arabic Linguistics, 6:16-55.

Reinhardt, Carl. 1972[1894]. Ein Arabischer Dialekt Gesprochen in Oman and Zanzibar [A]. Lehrbucher des Seminars fur orientalische Sprachen zu Berlin [C]. Amsterdam: Philo Press.

Rhodonakis, N. 1908. Der vulgararabische Dialekt im Dofar (Zfar). I. Prosaische und poetische Texte, Ubersetzung und Indices [A]. Kaiserliche Akademie der Wissenschaften, Sudarabische Expedition [C], Band 8. Wien: Alfred Holder.

Rhodonakis, N. 1911. Der vulgararabische Dialekt im Dofar (Zfar). II. Einleitung, Glossar und Grammatik [A]. Kaiserliche Akademie der Wissenschaften, Sudarabische Expedition [C], Band 10. Wien: Alfred Holder.

Ryding, Karin. 2005. A Reference Grammar of Modern Standard Arabic [M]. Cambridge: Cambridge University Press.

Shaaban, Kassim. 1977. The Phonology of Omani Arabic [D]. Doctoral Dissertation, Austin: University of Texas.

Sībawayhi, Abū Bishr. 1990[ $8^{\text {th }}$ century]. Al-Kitāb [M], Volume I. Cairo: Bulāq.

Tucker, Matthew. 2010. The morphosyntax of the Arabic verb: Toward a unified Syntax-Prosody [Z]. Ms. Santa Cruz: University of California.

Watson, Janet. 2002. The Phonology and Morphology of Arabic [M]. Oxford: Oxford University Press.

Webster, Roger. 1991. Notes on the dialect and way of life of the Āl-Wahība Bedouin of Oman [J]. Bulletin of the School of Oriental and African Studies, 54(3):473-485.

Wright, William. 1896. A Grammar of the Arabic Language [M], Volume 1. Cambridge: Cambridge University Press. 